\title{
Description of some Salticidae (Aranei) from the Malay Archipelago. III. Salticidae of Borneo, with comments on adjacent territories
}

\author{
Описание некоторых Salticidae (Aranei) из Малайского \\ архипелага. III. Salticidae Борнео, с комментариями \\ по соседним территориям
}

\author{
Jerzy Prószyński', Christa L. Deeleman-Reinhold ${ }^{2}$ \\ Й. Прушиньский ${ }^{1}$, К.А. Аелеман-РейнольА
}

\footnotetext{
${ }^{1}$ Museum and Institute of Zoology, Polish Academy of Sciences, ul. Wilcza 64, 00-679 Warszawa, Poland. E-mail: jerzy.proszynski@wp.pl

2 4619GA Ossendrecht, the Netherlands. E-mail: cdeeleman@planet.nl

${ }^{1}$ Музей и Институт Зоологии Польской Академии Наук, ул. Wilcza 64, 00-679 Варшава, Польша.

2 4619GA Ossendrecht, Нидерланды.
}

KEY WORDS: jumping spiders, new species, diagnostic characters, distribution, Borneo, Indonesia, Kalimantan, Malaysia, Sabah, Sarawak.

КЛЮЧЕВЫЕ СЛОВА: пауки-скакунчики, новые виды, диагностические признаки, распространение, Борнео, Индонезия, Калимантан, Малайзия, Сабах, Саравак.

ABSTRACT. This paper provides diagnostic drawings for selected Oriental genera and species, to complement the existing scanty literature. The following 16 new species are described: Bavia kahariana sp.n. $\left(0^{7}+\right)$, B. suhartoi sp.n. ( $\sigma^{\top}$ ), Cytaea semengohi sp.n. ( $\left.\sigma^{7}\right)$, C. sepakuensis sp.n. (+), C. trusmadii sp.n. (O'), Echeclus sokoli sp.n. ( $\left.\sigma^{\top}+\right)$, Euryattus kinabalus sp.n. $\left(\sigma^{\top}+\right)$, E. koomeni sp.n. $\left(\bigcirc^{7}+\right)$, E. pengi sp.n. $\left(\bigcirc^{7}\right)$, Onomastus danum sp.n. ( $\left.\sigma^{7}+\right)$, Pancorius petoti sp.n. (†), Poecilorchestes logunovi sp.n. $\left(\sigma^{7}\right)$, Sobasina platnicki sp.n. $\left(\bigcirc^{7}+\right)$, Stertinius onoi sp.n. $\left(\bigcirc^{7}+\right)$, Vailimia bakoensis sp.n. $\left(\sigma^{7}\right)$ and $V$. jianyuae sp.n. $\left(\sigma^{7}\right)$. One new species is described from New Guinea Euryattus ventralis sp.n. $(+)$. New female is added to Donoessus striatus Simon, 1902. Complementary, comparative drawings are given to 10 species: Bianor incitatus Thorell, 1890, Euryattus venustus (Doleschall, 1859), E. bleekeri (Doleschall, 1859), E. porcellus Thorell, 1881, E. venustus (Doleschall, 1859), Onomastus complexipalpis Wanless, 1980, O. kaharian Benjamin, 2010, O. simoni - abka, 1985, Pancorius dentichelis (Simon, 1899), Vailimia masinei (Peckham et Peckham, 1907). Genus name Orissania Prószyński, 1992 syn.n. is synonymised with the genus name Pancorius Simon, 1902 and a new combination Pancorius daitaricus (Prószyński, 1992) comb.n. ex Orissania daitarica Prószyński, 1992 is established. Three nominal species of Plotius: $P$. breviusculus Simon, 1902, P. celebensis Merian, 1911, $P$. leopoldi Roewer, 1938, are transferred back from Euryattus. Comments on subfamily Euophryinae are added.

РЕЗЮМЕ. В статье приведены диагностические рисунки ряда ориентальных родов и видов. Описано 16 новых видов из региона: Bavia kahariana sp.n.

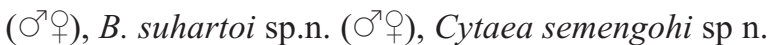
( $\left.\bigcirc^{7}\right), C$. sepakuensis sp.n. ( $(+)$, C. trusmadii sp.n. (O'), Echeclus sokoli sp.n. $\left(\sigma^{\top}\right)$, Euryattus kinabalus sp.n. $\left(\sigma^{\top}+\right)$, E. koomeni sp.n. $\left(\sigma^{7} \bigcirc\right)$, E. pengi sp.n. $\left(\sigma^{\top}\right)$, Onomastus danum sp.n. ( $\left.\sigma^{7}+\right)$, Pancorius petoti sp.n. $(+)$, Poecilorchestes logunovi sp.n. $\left(\sigma^{7}\right)$, Sobasina platnicki sp.n. ( $\sigma^{\top}+$ ), Stertinius onoi sp.n. $\left(\bigcirc^{7}+\right)$, Vailimia bakoensis sp.n. ( $\left.\sigma^{7}\right)$ и $V$. jianyuae sp.n. $\left(\sigma^{7}\right)$. Один новый вид описан из Новой Гвинеи Euryattus ventralis sp.n. (†). Приведено первоописание самки Donoessus striatus Simon, 1902. Дополнительные рисунки даны к 10 видам: Bianor incitatus Thorell, 1890, Euryattus venustus (Doleschall, 1859), E. bleekeri (Doleschall, 1859), E. porcellus Thorell, 1881, E. venustus (Doleschall, 1859), Onomastus complexipalpis Wanless, 1980, O. kaharian Benjamin, 2010, O. simoni Ïabka, 1985, Pancorius dentichelis (Simon, 1899) и Vailimia masinei (Peckham et Peckham, 1907). Род Orissania Prószyński, 1992 признан младшим синонимом Pancorius Simon, 1902. Предложена новая комбинация Pancorius daitaricus (Prószyński, 1992) comb.n. (ex Orissania daitarica Prószyński, 1992). Восстановлена первоначальная комбинация у трёх видов Plotius breviusculus Simon, 1902, P. celebensis Merian, 1911 и P. leopoldi Roewer, 1938. Ранее они рассматривались в роде Euryattus. Даны комментарии о подсемействе Euophryinae.

\section{Introduction}

This is the third part of a series of papers dealing with Salticidae of the Malay Archipelago [Prószyński \& Deeleman-Reinhold, 2010, 2012]. It defines a number of new, or poorly known species, creating a comparative basis for further taxonomic studies. The pre- 


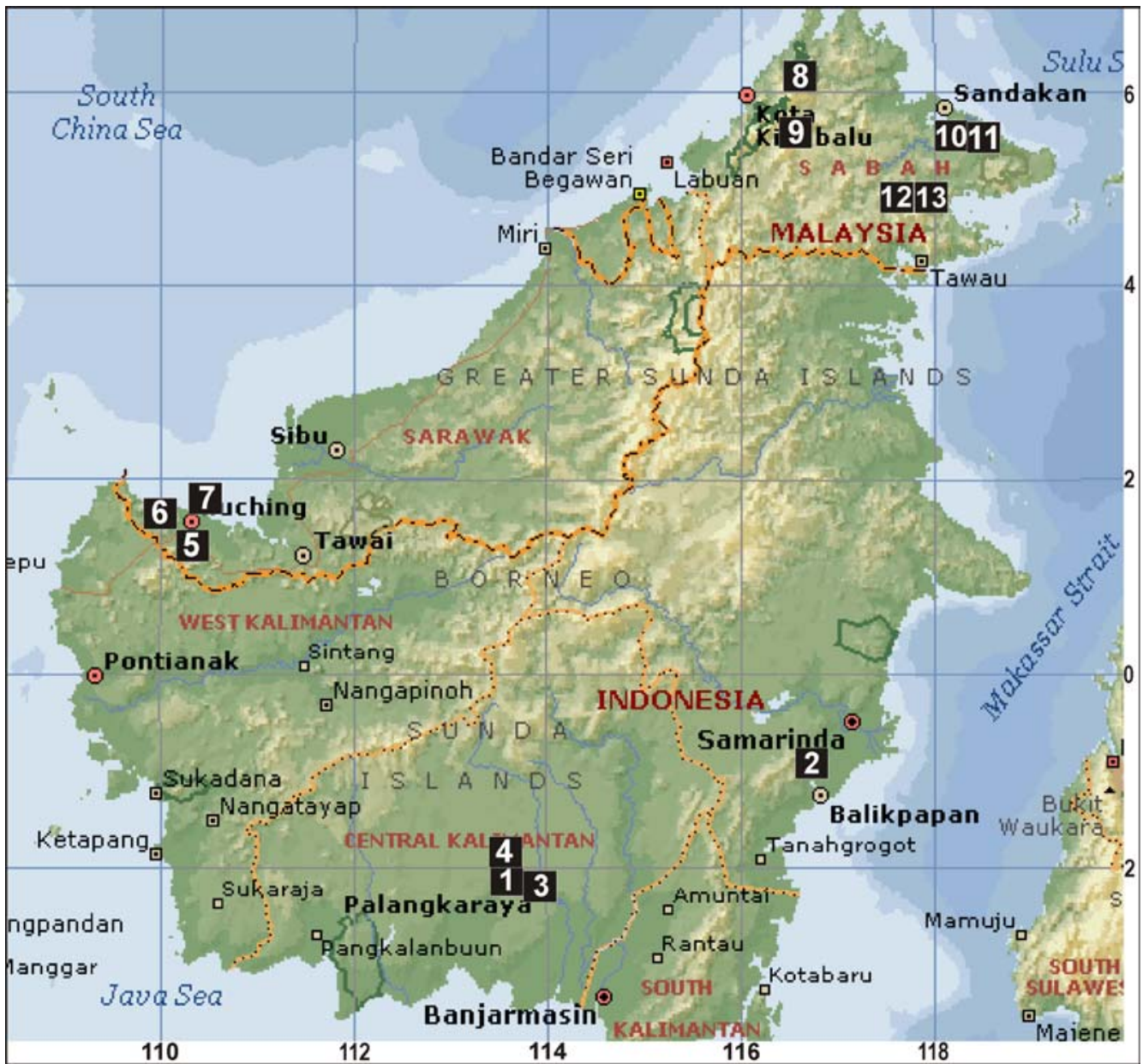

Map 1. Borneo Island with collecting localities. 1 - Kalimantan: Kaharian; 2 - Kalimantan: Sepaku; 3 - Kalimantan: Palangkaraya; 4 - Kalimantan: 40 km NW of Palangkaraya; 5 - W Sarawak: Semenggoh Arboretum; 6 - Sarawak: Matang Reserve; 7 W Sarawak: Bako National Park; 8 - W Sabah: National Park Kinabalu; 9 - W Sabah: Trus Madi Commercial Forest Reserve; 10 - E Sabah: Sukau-Bukit Tomanggong Besar, 11 - E Sabah: Sukau; 12 - E Sabah, Danum Valley Field Centre; 13 - E Sabah, Danum Valley Conservation Area.

Карта 1. Остров Борнео и места сбора.

requisite for extensive taxonomic studies is the preparation of complete documentation of the diagnostic characters for all relevant species. This is far from accomplished for the Malay Archipelago, for instance 140 nominal species were reported from Borneo (351 from all Indonesia), of which only 35 have diagnostic drawings for both sexes ( 88 in Indonesia), and 31 have no drawings of any kind. That means that only one quarter of the species can be recognized and classified, but that classification is unsure in many cases. Existing diagnostic drawings of Salticidae in the literature, are summarized in the Internet database "Monograph of Salticidae (Araneae) of the World" by Prószyński [2012: online, a summary of all previous versions since 1995].

Also, our knowledge of the geographical distribution within this highly diverse tropical fauna, resulting from intensive speciation, is very incomplete. The present state of knowledge of the Malayan Archipelago fauna is a result of some 150 years of collecting and describing, with gloomy forecasts for the future development of research, seriously hampered in some coun- tries by bureaucratic bans on collecting in natural habitats, many of which are destined for imminent destruction anyway. Some improvement of the situation may be expected from the broader application of new documentation methods, such as the photographic plates by P. Koomen presented in this paper (Figs 41-47, 5678 ), being a sample of a total of 140 similar plates showing 47 species, shown in Prószyński [2012]. Photo-documentation could be produced by numerous photographers/amateur naturalists, which may facilitate a quick increase in our knowledge of the fauna.

The genera and species are classified provisionally, pending revisions of related genera, especially their insufficiently studied type specimens. The faunal relationships between larger islands and groups of smaller islands cannot be resolved yet, although some hints are discernible even from the preliminary data.

An untapped source of taxonomic information are photographs of Salticidae, available now on the Internet, some of which are used in this paper to draw attention to particularly interesting species. The au- 
thors realize the limited sample sizes of the described material, but assume that it will promote future taxonomic research.

\section{Materials and methods}

The research was done on specimens singled out from the collection of C.L. Deeleman-Reinhold (CDML), donated to the Nationaal Natuurhistorische Museum ("Naturalis") (formerly Rijksmuseum van Natuurlijke Historie) in Leiden, the Netherlands, but physically still stored in her home in Ossendrecht. The holotypes are marked in the collection by red chips, paratypes by blue chips.

Specimens studied in this paper are kept in the following collections:

BCPK - Sabah spider collection of P. Koomen, Leeuwarden, the Netherlands (to become part of the Borneensis Collection of the Universiti Malaysia Sabah, Kota Kinabalu, Sabah-Malaysia).

CDML - Collection of C.L. Deeleman-Reinhold, donated to Rijksmuseum Leiden, but physically still stored in her home in Ossendrecht (2011).

MCZ - Museum of Comparative Zoology, Harvard University.

NHRS - Natural History Museum, Stockholm.

Collectors names abbreviations: D-R - C.L. Deeleman-Reinhold, SD - Suharto Djojosudharmo.

The original examination of the specimens was carried out in the 1990s, as the beginning of planned, more extensive studies, which unfortunately did not materialize. The relationships of the described species are illustrated by drawings of relevant species taken from the literature [Prószyński, 1984b, 1987, and others].

Specimens were studied under stereomicroscope, with magnification up to $100 \mathrm{x}$ (with an additional $2 \mathrm{x}$ objective lens giving 200x). Palpal organs were detached, fixed in sand in an ethanol filled Petri dish. After examination they were put in microvials together with the original specimens.

The epigyne was drawn from the intact specimen, and then cut off for examination of internal structure. The tip of a small scalpel was slid under epigyne, then integument around was cut, epigynal plate placed in $10-20 \%$ aqueous $\mathrm{KOH}$ solution and cleared for about 24-72 hours (in room temperature), later stained in Chlorazol Black E alcohol solution, mounted on a temporary slide in clove oil, and examined under a compound microscope (objectives 20x and for details 40x). Subsequently, the epigynes were deposited in a microvial with ethanol and stored together with the original specimen.

All drawings were made with a square net micrometer (ocular graticule with squares), on a paper with temporary faint grid (with dimension selected to fit requested drawing size).

Species are defined in this paper by pictures of their genital organs and body features, studied in single specimens and compared with drawings of type species and all other species of each genus, shown in Prószyński [2012]. There was no possibility to study morphological variation within species. Furthermore, appearance of specimens is changed as a result of their long preservation, so careful comparisons with fresh specimens will be required in the future. All measurements are in $\mathrm{mm}$, approximate because taken from drawings. Descriptions and remarks on particular taxa are presented in this paper in an alphabetic order.

\section{Taxonomic survey}

\section{Genus Bavia Simon, 1877}

Type species Bavia aericeps Simon, 1877, widely distributed in SE Asia and Pacific Islands.

REMARKS. Simon [1901: 469] classified this genus into a heterogeneous group of genera Baviae, characterized by the presence of multiple minute teeth accompanied with numerous hairs on the inner posterior cheliceral margin and the body shape; several of these genera have already been reclassified into the subfamily Euophryinae. The genus contains 20 described species, six of which having no diagnostic drawings of any kind, there are also several species pending formal taxonomic description. These are relatively large spiders (about $10 \mathrm{~mm}$ long), characterized by a broad carapace and long, narrow abdomen, pointed posteriorly, with legs I longest and robust. While the external appearance of these spiders is similar, there is extensive diversity in the structure of the palpal organs, requiring further revisionary studies. The embolus protruding from under the edge of a white plate covering the anterior bulbus, may appear short and broad in several species, whereas in other species it is long and thread-like. However, these structures may not be so different, because the part of the embolus hidden under the bulbus, dorsally to it, has not been studied. Recent photographs of the thread-like embolus in B. suharto sp.n. (Figs 14-16) show that it arises from the dorsal surface of the bulbus, invisible in the standard examination positions of the palpus, i.e. in ventral and lateral views. It can be seen only in an oblique, ventro-lateral position of the segment or, perhaps, through dissection. In B. kahariana sp.n. (Figs 4, 6) there is a diamond-shaped broadening in the mid-length of the embolus, which possibly plugs the copulatory duct of the female, when broken off during mating. The internal structures of the epigyne are strongly sclerotized, deserving further study and, presumably, splitting of the genus in the future (Figs 8, 20). Given this diversity, the delimitation of the genus and the classification of the species within it are uncertain.

\section{Bavia kahariana sp.n.}

Figs 1-9.

MATERIAL. Holotype + , allotype $\sigma^{\top}$, paratypes $4 \sigma^{7} \sigma^{7}, 1 \%$, S Kalimantan, Kaharian 2Ú02'S, 113Ú40'E, primary peat bog forest, 2-16.09.1985 (SD). Paratypes $2 \sigma^{\top} \sigma^{7}, 1 \stackrel{\circ}{\circ}$, Borneo, C.Kalimantan, 


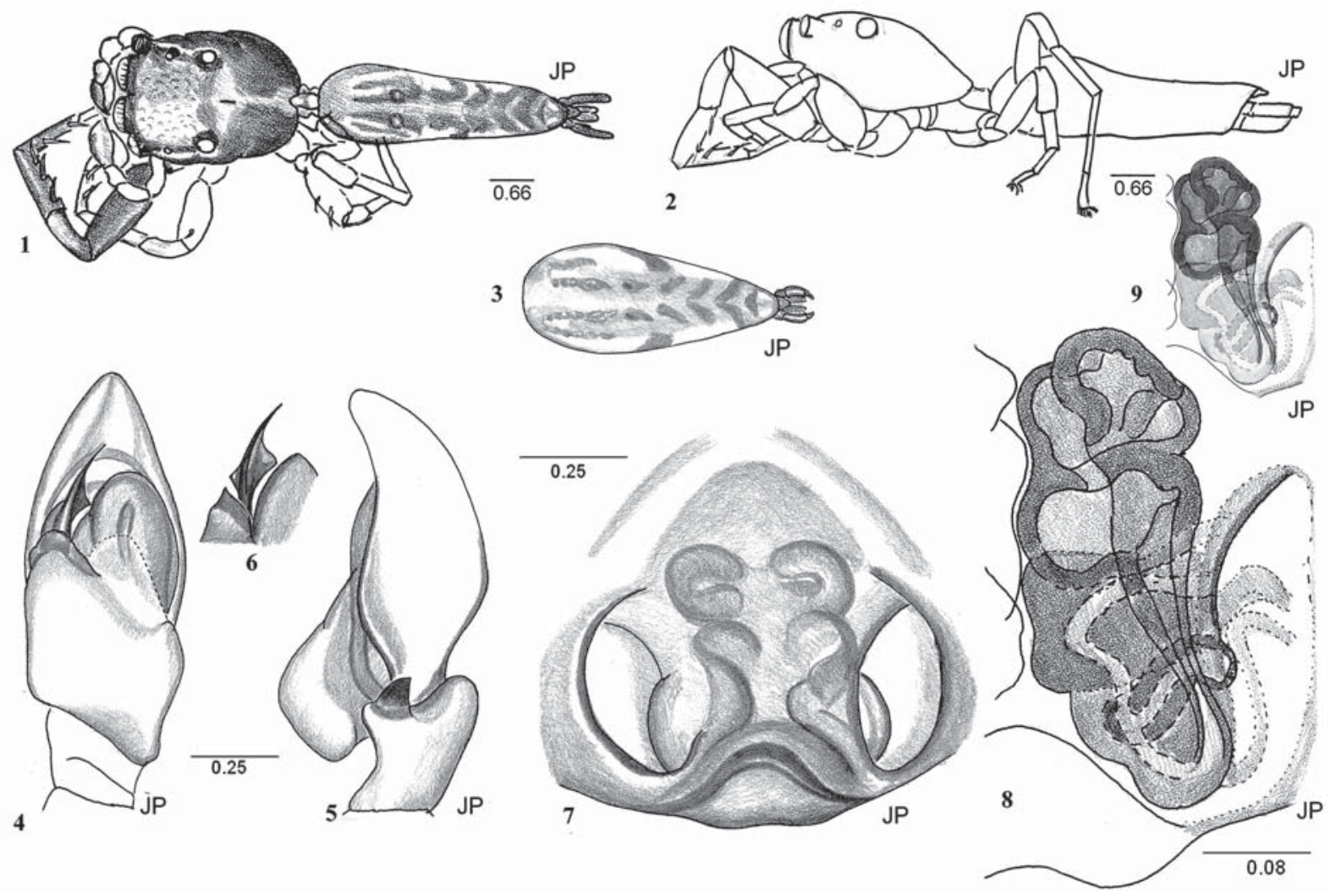

Figs 1-9. General appearance and copulatory organs of Bavia kahariana sp.n. 1-2 - general appearance of male, dorsal and lateral views; 3 - abdominal pattern in female; 4-5 - palpus, ventral and lateral views; 6 - tip of embolus with lateral expansion; 7 - epigyne; 8 - spermatheca and duct; 9 - diagram showing alternative interpretation of spermatheca.

Рис. 1-9. Общий вид и копулятивные органы Bavia kahariana sp.n. 1-2 - Общий вид самца, сверху и сбоку; 3 - рисунок брюшка самки; 4-5 - пальпа, снизу и сбоку; 6 - кончик эмболюса; 7 - эигина; 8 - сперматека и трубка; 9 - диаграмма с альтернативной интерпретацией сперматеки.

“Tumbang Tahai", $2^{\circ} 2^{\prime} \mathrm{S}, 113^{\circ} 35^{\prime} \mathrm{E}$, primary peat bog forest, 2 16.09.1985, leg. Suharto Djojosudharmo. CDML. Paratypes $2 \sigma^{7} \sigma^{r}$, $40 \mathrm{~km}$ from Palangkaraya, secondary forest, 09.1985 (SD). CDML.

DIAGNOSIS. Resembling type species $B$. aericeps [Prószyński, 2012: online] by body shape (Figs 1-3), but differs by structure of spermatheca and dorsal pattern (Figs 7-9). Palpal organ (Figs 4-6) resembling $B$. annamita [Żabka, 1988, figs 45-46, 50-51] by long thin embolus, which in $B$. aericeps appears short and broad.

DESCRIPTION. Male. Carapace broad, eyefield occupies half the length of the carapace, slightly narrowing posteriorly, thorax gently sloping. Abdomen narrow and long, lower than carapace (Figs 1-2). Eyefield delimited laterally by thin white lines, posteriorly by a narrow transverse white spot, thorax with indistinct median light line. Abdomen elongate, narrow and low, gradually narrowing posteriorly. Abdominal dorsal pattern complicated and irregular, consisting of two pairs of gray spots medially along anterior third, remaining part of abdomen with gray reverse oriented chevron marks; there are irregular white marginal lines, broken into 2 pairs of spots. Legs long, leg I robust, with dark femur, tibia and metatarsus, tibia I with three pairs of robust, ventral spines, metatarsus with two pairs.
Measurements (approximate): length of carapace 2.4 , length of eyefield 1.3, width of eyefield at eyes I 1.7 , width of eyefield at eyes III 1.5 , width of carapace 2.0 , height of carapace 1.3 , length of abdomen 3.5 , width of abdomen 1.0.

Palpus (Fig. 4) with embolus arising parallel to bulbus at $1 / 3$ of its length, from a broad base, bulbus relatively narrow but with prominent posterior ventral bulge (Fig. 5). Embolus protruding from beneath bulbus edge, short, with diamond-shaped lateral extension in the middle (Fig. 6), presumably used as a breakable plug to block the female's copulatory duct at the end of mating - if that supposition is true, it may be absent in mated males. Tibial apophysis a massive trapezoid, broad at the tip, with lateral surface covered densely with small, round and flattened little warts.

Female holotype. External appearance resembling male, with abdominal pattern somewhat simplified (Fig. $3)$. Epigyne broad oval, with two broad grooves laterally (Fig. 7). Spermatheca in the form of a single, heavily sclerotized compact body with internal complicated convoluted chambers and ducts (Fig. 8). Alternatively, it can be interpreted as two sclerotized bodies connected by a long and thin, longitudinal superficial 
duct (Fig. 9). Preferential selection of one of these interpretations requires further studies.

DISTRIBUTION. Documented from Borneo: Kalimantan: Kaharian (Indonesia).

\section{Bavia suhartoi sp.n.}

Figs $10-20$.

MATERIAL. Holotype + , allotype $\sigma^{7}$, paratypes $2 \sigma^{7} \sigma^{7}, 13$ 우, S Kalimantan: Kaharian, 2Ú02'S, 113Ú40E, primary peat bog forest, 2-16.09.1985 (SD). CDML.

ETYMOLOGY. Named for the late Mr. Suharto Djojosudharmo, collector of rich spider material from Indonesia.

DIAGNOSIS. Body shape and proportions (Figs $10,18)$ resemble $B$. kahariana sp.n. (Figs 1-3), but genital organs differ in having a long thin embolus and elongate tip of the cymbium in the male (Figs 14-17), and in the female by the shape of the epigyne, particularly its internal structures (Figs 19-10). Palpus closely resembles $B$. sonsorol Berry, Beatty et Prószyński [1997: 120-121, figs 43-44, 48], but has a broader, more rounded bulb and a deeper cleft between the rami of the tibial apophysis.

DESCRIPTION. Male. Carapace oval, indistinctly broader than eyefield, thorax gently sloping, brown (Fig. 10). Eyefield rectangular, 1.4 times wider than long. Anterior lateral eyes small, their diameter 2.7 times smaller than anterior median, aligned with their upper rim (Fig. 12). Abdomen elongate oval, 1.2 times longer than carapace, its color pattern is shown in Fig. 10. Legs I distinctly longest, with dark brown, robust femur, patella and tibia, metatarsus thinner and dark, and tarsus light. Legs II-IV slender, light. Chelicerae elongated and broad (Figs 11-13), with triangular transverse expansion of prolateral edge. There is a row of numerous, minute teeth along posterior inner margin, and a row of dense and long hairs along the inner anterior edge. Anterior, spine-like extension near fang socket (Fig. 13), anterior surface of chelicerae inclined obliquely. Palpus long, with dark femur and basal half of cymbium, contrasting with light distal end of cymbium, tibia and patella (Figs 11, 17). Bulbus elongate with longitudinal loop of broad spermophor, posteriorly white and prominently broadened forming a prolaterally rounded bulge, anterior part of that produces whitish, semitransparent sheet, covering one third of length of bulbus. Embolus runs laterally from the basal part of the tegulum, is gently bent, half of its length expands in front of the bulbus Fig. 14). The exact point of origin of the embolus is visible only after turning the segment into an oblique ventro-lateral position, in ventral position it is obscured by the prolateral bulge of the bulbus. Embolus filiform, originates from dorsal surface of the bulge and makes original broad loop, with a dorsal conical branch (Fig. 16). It continues around base of the bulbus and extends along the groove at tip of cymbium. Tibial apophysis short and broad, terminating with short, sclerotized tooth-like process (Figs 16-17). It is separated from more dorsal part of tibial rim by a prominent cleft.

Female holotype. General appearance of body resembles male. Body elongated, abdomen 1.7 long, 0.86 wide, with remnants of complicated dark pattern (Fig. 18). Epigyne complicated, strongly sclerotized, with two large lateral depressions and two posterior small processes, possibly forming posterior pockets (Fig. 19). Copulatory opening lateral, at mid-length of epigyne. Copulatory duct broad but short, leads to the posterior chamber of spermatheca, which is oval and has a sclerotized duct leading to anterior chamber of spermatheca. There is a prominent, chimney-like duct leading to the scent opening. Anterior chamber of spermatheca contains internal convoluted channel and has small, conical protuberance (Fig. 20).

DISTRIBUTION. Documented from Borneo: Kalimantan: Kaharian (Indonesia).

\section{Bianor incitatus Thorell, 1890}

Figs 21-24.

MATERIAL. $1 \sigma^{7}$, Bianor? sp., Kalimantan: Sepaku, 40 km N of Balikpapan, isolated stand of swampy primary forest, 16.06.1979 (D-R). CDML.

DIAGNOSIS. Differs from B. maculatus (Keyserling, 1883), the type species, by having the anterior flattened of rim of the bulbus perpendicular to the main axis, rather than diagonal to it, also the tibial apophysis is more robust.

DESCRIPTION. Male. Carapace high, highest at eyes III, slightly shorter than abdomen and moderately broad. Eyefield lighter than carapace. Thorax short, with steep posterior slope and indistinct medial light line (Figs 21-22). Abdomen oval, slightly narrower than carapace, with faint trace of a pair of lighter posterior spots. Large oval plate dorsally on abdomen resembling scutum, however presumably not visible in live specimens. Palpus characteristic for Bianor, with bulbus round, anterior edge indistinctly flattened, that flattening is perpendicular to the main axis and not diagonal (Fig. 23). Tibial apophysis relatively broad and long, indistinctly shorter than diameter of bulbus, slightly wavy in lateral view (Fig. 24).

Female unknown.

REMARKS. All species of Bianor are relatively similar in appearance; the identification of a single male is uncertain [Logunov, 2000: 221-286].

DISTRIBUTION. Documented from Borneo: Kalimantan: (Indonesia). Reports from other countries uncertain.

\section{Genus Cytaea Keyserling, 1882}

Type species Cytaea alburna Keyserling, 1882 from Australia.

REMARKS. The genus Cytaea, belonging to the subfamily Euophryinae, contains 67 nominal species, but only 11 have diagnostic drawings for both sexes and 14 have drawings for one sex only. Sixteen species 


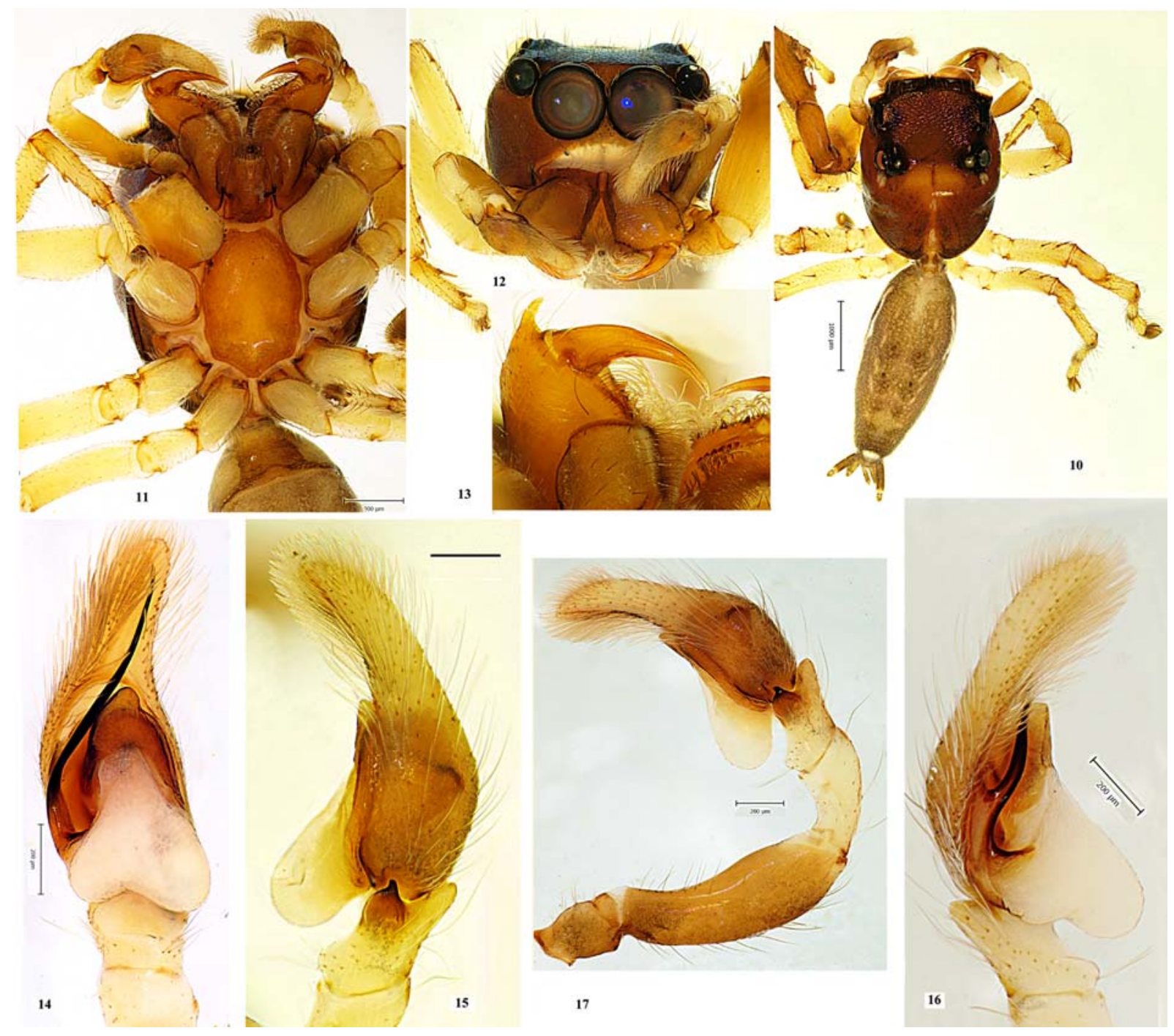

Figs 10-17. General appearance and palpus of male paratype of Bavia suhartoi sp.n. 10 - dorsal view; 11 - prosoma, ventral view; 12 - face; 13 - chelicera, ventral view; 14-16 -cymbium and palpal tibia: ventral, retrolateral and prolateral views; 17 - palpus, retrolateral view. $10-17$ - photo by Yu.M. Marusik.

Рис. 10-17. Общий вид и пальпа самца у паратипа Bavia suhartoi sp.n. 10 - сверху; 11 — просома, снизу; 12 — «лицо»; 13 хелицера, снизу; 14-16 - цимбиум и голень пальпы, снизу, ретролатериально и пролатерально; 17 - пальпа, ретролатерально. $10-17$ - фото Ю.М. Марусика.

have been reported from Australia, 22 from Pacific Islands, ten from Indonesia and one from Borneo.

DESCRIPTION. Body stout, covered by light-reflecting scales, medium high, with carapace broad, posteriorly semicircular, eyefield broader than long, rectangular. Carapace with characteristic white band along margins and, often, central light spot near fovea, broad diamond-shaped. Abdomen about as long as carapace, but narrower (Figs 32-33, 41-42). Face with anterior eyes aligned along their dorsal rim, lateral eyes about half the size of medians (Fig. 43). Clypeus low, usually covered with longer white hairs. Chelicerae slender, short, often with dark, transverse band. Inner posterior tooth with two cusps (Fig. 47). Palpal organ with broad bulbus, meandering spermophor, embolus forming a large, flat coil in anterior part of bulbus (but some species have small embolic coil, sometimes only part of a coil). Epigyne with two large oval 'windows' or grooves, globular spermathecae small, copulatory ducts sclerotized, forming complicated loops, which differ from simple ducts in comparative species Euophrys wanyan Berry, Beatty et Prószyński, 1996 (Fig. 40) from nearby Palau Is.

\section{Cytaea semengohi sp.n.}

Figs 32-35.

MATERIAL. Holotype $\sigma^{\top}$, Borneo Isl.: W Sarawak: Semengoh Arboretum, upper trail, beating shrub, 27.03 .1985 (D-R). [Attention: 9 in this vial is Donoessus — see above]. CDML.

ETYMOLOGY. Name derived from the collecting area. 


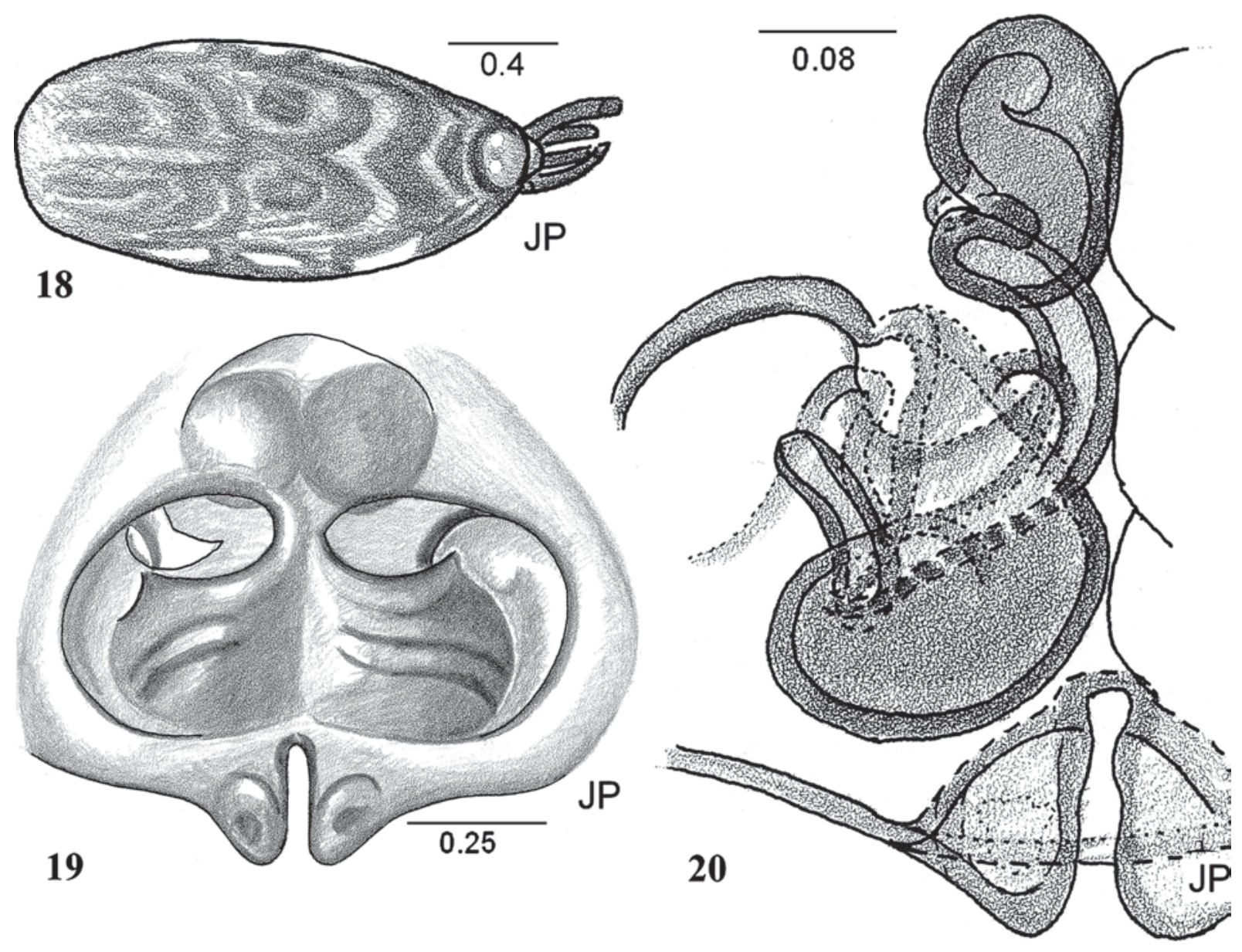

Figs 18-20. Abdominal pattern and epigyne of holotype female of Bavia suhartoi sp.n. 18 - abdominal pattern; 19 - epigyne and its internal structure. 20 -internal structure of epigyne.

Рис. 18-20. Рисунок брюшка и эпигина голотипа Bavia suhartoi sp.n. 18 - рисунок брюшка; 19 - еріgуnе и её внутренние структуры; 20 - эпигина, сверху.

DIAGNOSIS. Male palpus differs from the type species by having a shorter, almost square bulbus and a broader apophysis (Figs 34-35).

DESCRIPTION. Male. Small spider (total length 2 $\mathrm{mm})$. Light colored, with dark lateral margins of eyefield and small, triangular dark spot on posterior slope of carapace (Figs 32-33). Carapace broad, rounded posteriorly, high, with steep posterior slope, eyefield extends over $3 / 5$ of the carapace. Abdomen oval, narrower than carapace, narrowing posteriorly, indistinctly lower than carapace. Color pattern of abdomen light, apparently faded, with indistinct darker thin lines, arranged into two transverse belts, as well as medial longitudinal line in anterior half of abdomen (Fig. 33). Palpus with meandering spermophor duct and embolus forming half a loop in front of tegulum. Embolus arises from basal semicircular pad at 5 o'clock. Bulbus almost square. Tibial apophysis narrow, slightly inclined and indistinctly bent, as long as palpal tibia (Figs 34-35).

Measurements (approximate): length of carapace 1.0 , length of eyefield 0.6 , width of eyefield at eyes I
0.9 , width of eyefield at eyes III 0.7 , height of carapace 0.7 , length of abdomen 1.0, width of abdomen 0.6 , height of abdomen 0.6 .

DISTRIBUTION. Documented from Borneo: Sarawak (Malaysia).

\section{Cytaea sepakuensis sp.n.}

Figs 38-39.

MATERIAL. Holotype + , Kalimantan: Sepaku, $40 \mathrm{~km} \mathrm{~N}$ of Balikpapan, rainforest, 16.06.1979 (D-R). CDML.

DIAGNOSIS. Epigyne and spermatheca resemble type species in size and proportions, but differ by the unusually long copulatory duct of the epigyne, twisted into a single, almost complete coil near the copulatory opening, and three irregular coils before joining the globular spermatheca (Fig. 39).

DESCRIPTION. Male unknown.

Female. Body small. Carapace and abdomen of comparable width and length, abdomen slightly wider. Height of carapace equal to length of eye field, posterior slope steep. Carapace brown with dorsal surface 

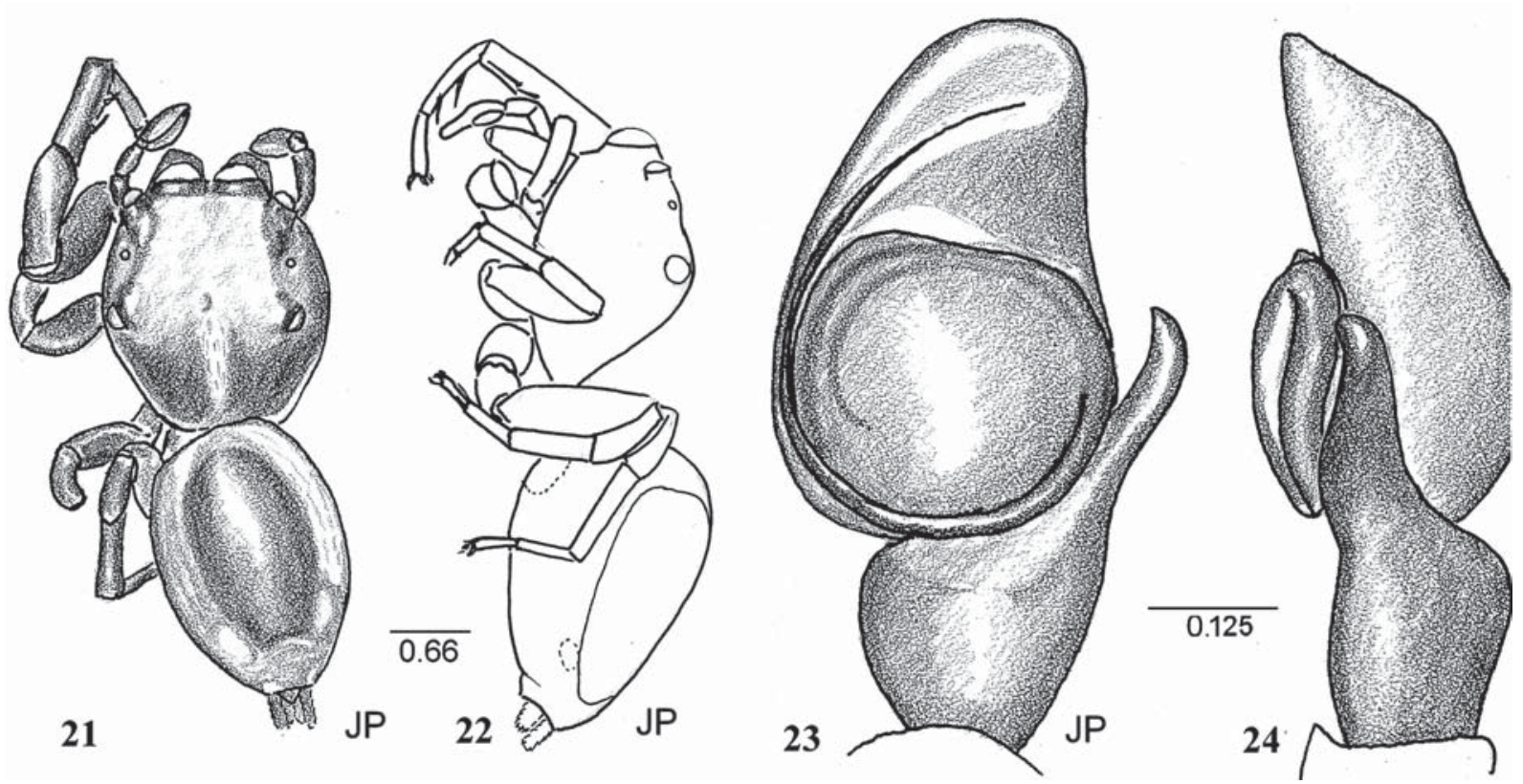

Figs 21-24. General appearance and copulatory organs of Bianor incitatus Thorell, 1890 from Kalimantan. $21-22$ - general appearance, dorsal and lateral views; $23-24$ - palpus, ventral and lateral views.

Рис. 21-24. Общий вид и копулятивные органы Bianor incitatus Thorell, 1890 из Калимантана. 21-22 - общий вид, сверху и сбоку; 23-24 - пальпа, снизу и сбоку.

lighter brown, with very sparse, minute hairs, eyefield with a very fine rugosity. Traces of narrow belt of whitish scales and hairs along ventral margin of carapace. Abdomen light grayish brown, with rows of small, sparse dots of white scales over anterior half. Clypeus brown, almost bald with a few white hairs, its height close to half the diameter of anterior median eyes, diameter of anterior laterals is shorter by 0.2 from the medians. Chelicerae small, with single large tooth on retrolateral edge. Legs light brown, of similar size, IV longest, a patch of small white scales along dorsal surface of tibia I. Epigyne with single white, membranous 'window', constricted in the middle but without septum, with rims sclerotized and dark. Copulatory openings indistinct, in the centre of each half of the 'window' (Fig. 38). Copulatory duct consists of a circular coil, which then runs diagonally posteriorly, to form two half coils in planes perpendicular to each other, then after another small, circular loop, enters spermatheca by an almost level, gently bent stretch (Fig. 39). Initial, short part of the duct membranous, remaining part sclerotized, scent gland opening armature short and chimney-like, located within first loop of the duct. Spermatheca almost spherical, with walls sclerotized, slightly thicker than copulatory ducts, with distinct cone-like base of the fertilization duct. There is a depression in the wall nearby, from which a bunch of nutritive pores arises.

REMARKS. Classification in the genus Cytaea is tentative. The copulatory duct and spermatheca resemble those of Lakarobius alboniger Berry, Beatty et Prószyński, 1998 [Berry et al., 1998: fig. 40], from Viti
Levu, but the body shape and color pattern of that species is distinctly different. The internal structure of the epigyne is also comparable with several species of Cytaea described by Berry et al. [1998] from Caroline and the Fijian islands: C. koronivia [op. cit., fig. 15], C. nausori [op. cit., fig. 20], C. ponapensis [op. cit., fig. 25] and C. vitiensis [op. cit., fig. 35]. The external appearance is comparable with the female of $C$. oreophila Simon, 1902 from Singapore [Prószyński, 2012].

DISTRIBUTION. Documented from Borneo: Kalimantan: Sepaku (Indonesia).

\section{Cytaea trusmadii sp.n.}

Figs 41-47.

MATERIAL. Holotype $\sigma^{7}$, Borneo Isl.: Sabah: Trus Madi Commercial Forest Reserve, lower montane primary forest, partly logged, herbs and bushes along road verges, between $5^{\circ} 35.214^{\prime} \mathrm{N}$ $116^{\circ} 29.266^{\prime} \mathrm{E}$ and $5^{\circ} 34.484^{\prime} \mathrm{N} 116^{\circ} 29.177^{\prime} \mathrm{E}$, alt. $1750-1850 \mathrm{~m}$, 27.10.2001 (leg. J.P. King). BCPK.

Paratype O ${ }^{2}$, Borneo Isl: Sabah: Trus Madi Commercial Forest Reserve, lower montane primary forest, along trail to summit, between $5^{\circ} 34.064^{\prime} \mathrm{N} 116^{\circ} 29.120^{\prime} \mathrm{E}$ and $5^{\circ} 33.639^{\prime} \mathrm{N} 116^{\circ} 29.271^{\prime} \mathrm{E}$, alt. 1750-1850 m, 25.10.2001 (leg. M. Schilthuizen \& P. Koomen). BCPK.

ETYMOLOGY. Species named after its type locality, the Trus Madi mountain (trusmadii noun, male, genitive)

DIAGNOSIS. Body size and proportions (Figs 4142) similar to those in $C$. semengohi sp.n., but $C$. trusmadii sp.n. differs by having a circular basal embolic pad, a longer embolus, an extensive prolateral swelling of the bulbus and a shorter palpal tibia (Figs 45-46). 

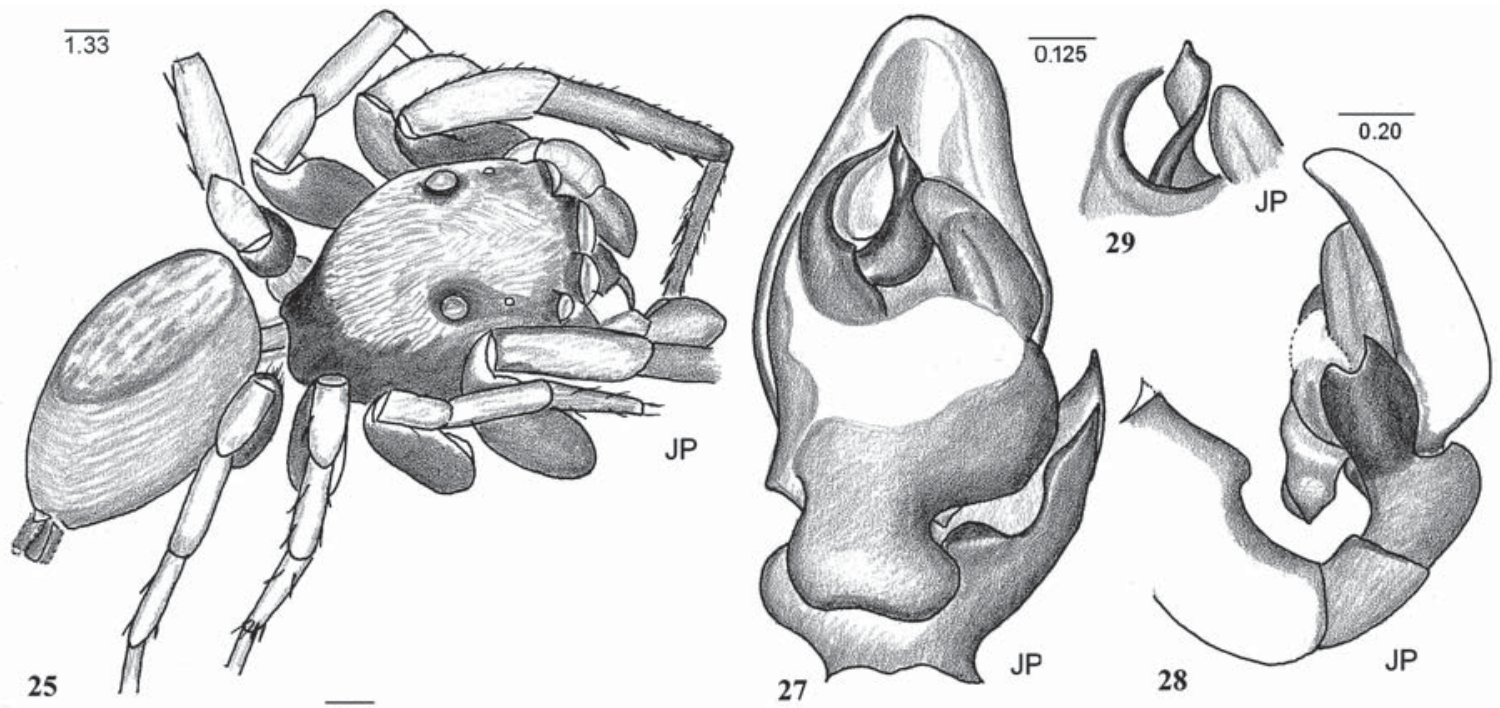

$\overline{0.125}$

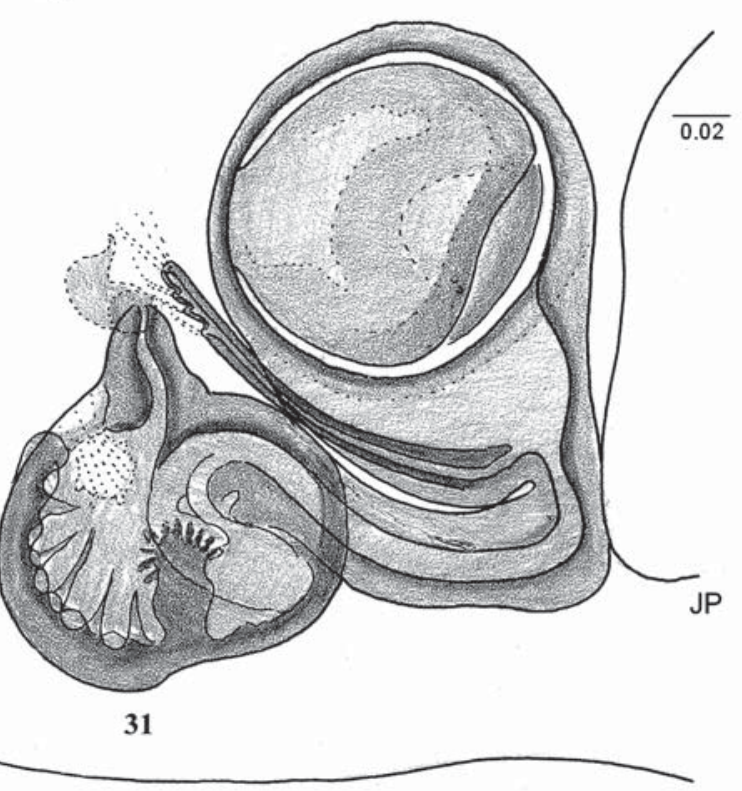

Figs 25-31. General appearance and copulatory organs of Echeclus sokoli sp.n. 25 - general appearance; 26 - cheliceral dentition; 27-28 - palpus, ventral and lateral views; 29 - embolus and tip of bulbus; 30-31 - epigyne and its internal structures.

Рис. 25-31. Общий вид и копулятивные органы Echeclus sokoli sp.n. 25 - общий вид; 26 - вооружение хелицер; 27-28 пальпа, снизу и сбоку; 29 - эмболюс и вершина бульбуса; 30-31 - эпигина и её внутренние структуры.

DESCRIPTION. Male. Carapace high, the highest point being the rims of eyes III, eyefield gently sloping anteriorly at about $20^{\circ}$, anterior half of thorax sloping posteriorly at about $20^{\circ}$, the posterior half is more abrupt, sloping at about $75^{\circ}$ (Fig. 42). Length of carapace equal to about one and half times its height, thoracic region about one third shorter than eyefield. Sides of carapace vertical. Abdomen oval, slightly shorter and lower than carapace, in the holotype broadest at about $2 / 3$ of its length (Fig. 41 ), in the paratype that broadening is less distinct. Color pattern dark brown on whitish background, on abdomen grayish brown, mottled whitish, paratype is lighter, presumably faded during prolonged preservation. Eyefield light brownish between black pigmented screening areas of lateral and anterior eyes. Thoracic part and sides whitish, with dark brown streaks and spots, foveal dark streak stretches along flat part of thoracic region, broadened posteriorly. Slope of carapace white, divided into two streaks by dark mid-slope streak, and delimited by dark brown rims of carapace. Abdomen with complicated pattern of grayish brown spots and lines on whitish background. Spinnerets light, the dorsal pair darker gray. Face with anterior lateral eyes aligned to upper half of the diameter of anterior median eyes, their diameter one third shorter than the latter (Fig. 43). Clypeus low, white, continuous with white sides of carapace, which are four times higher than clypeus. Surrounds of eyes I 

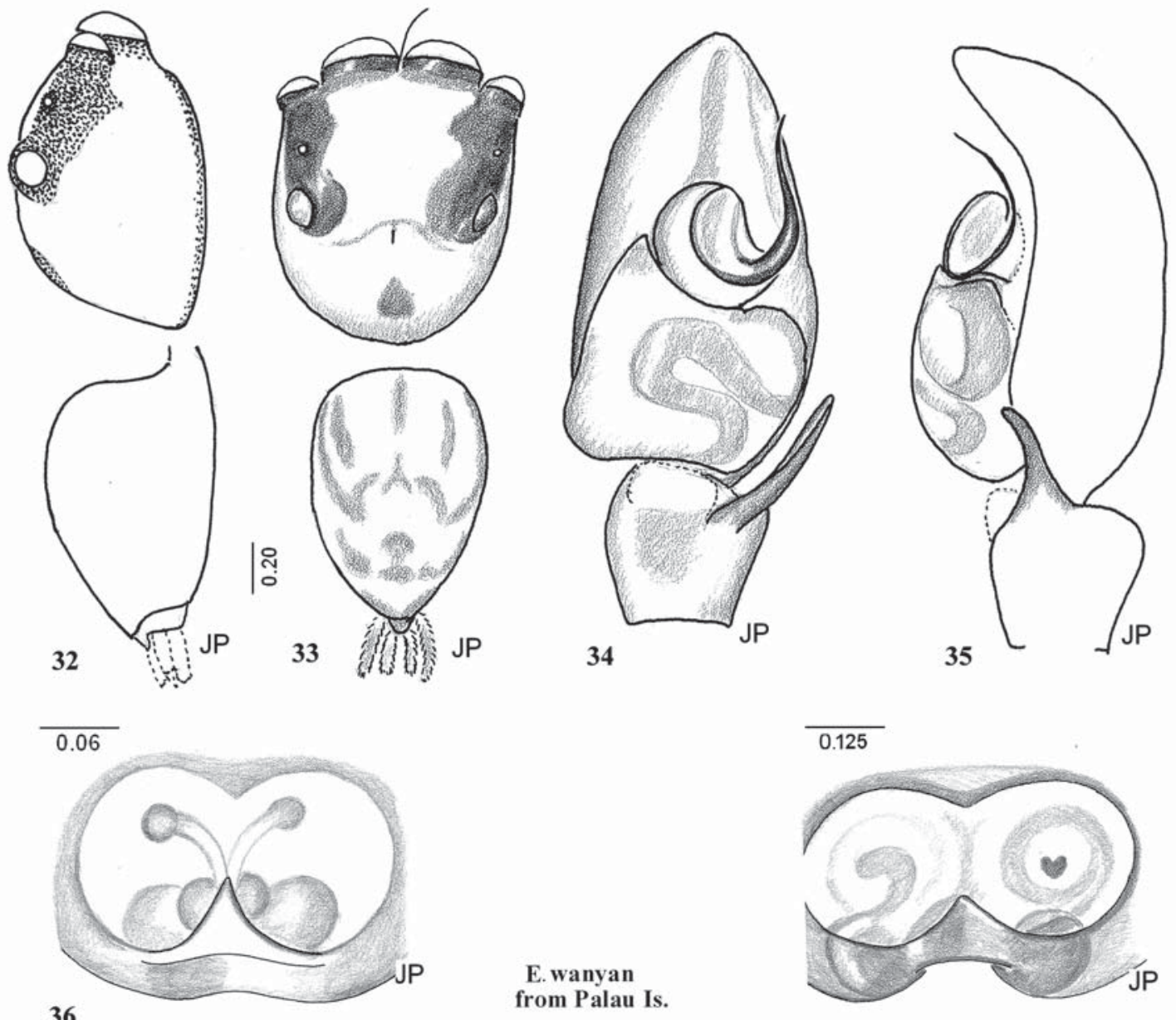

36

E. wanyan from Palau Is.
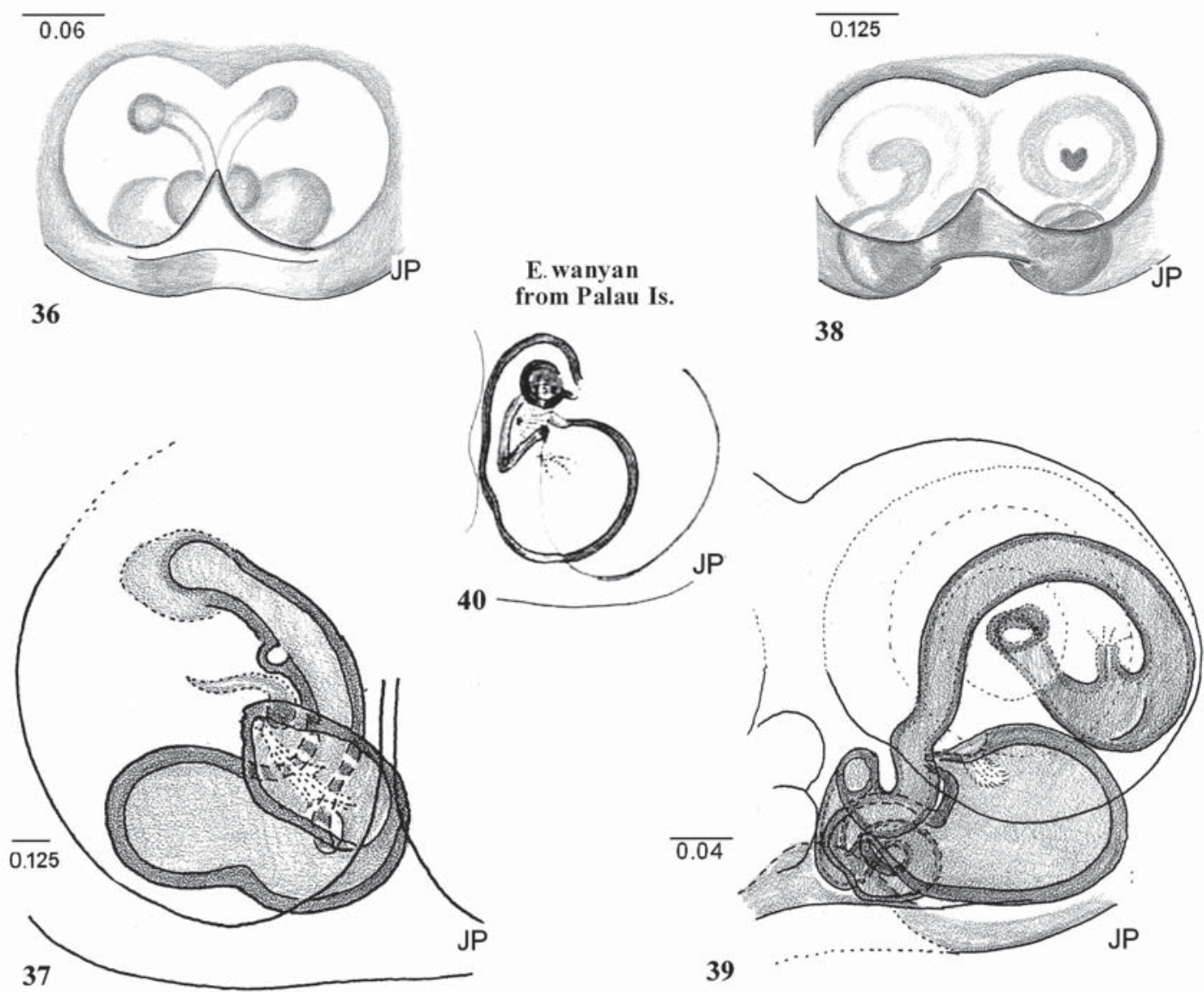

38

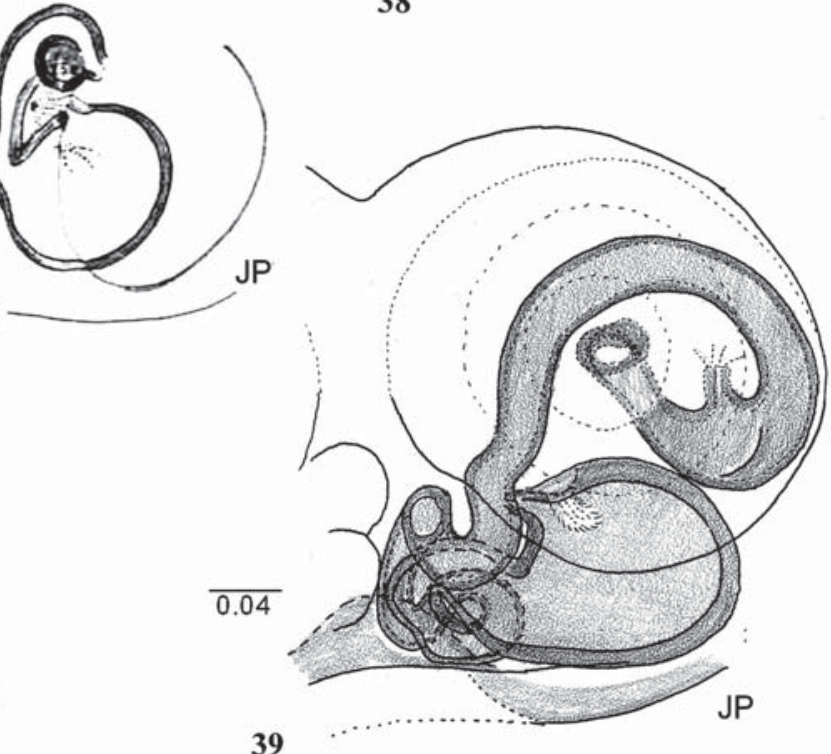

Figs 32-40. General appearance and copulatory organs of Cytaea semengohi sp.n. (32-35), C. sepakuensis sp.n. (36-37); Donoessus striatus (38-39), Euophrys wanyan (40); 32-33 - general appearance, dorsal and lateral views; 34-35 - palpus, ventral and lateral views; 36, 38 - epigyne; 37, 39-40 - internal structures of epigyne. 32-39 - from Borneo Isl.; 40 - from Sumatra. $40-$ after Prószyñski et al. [2012a].

Рис. 32-40. Общий вид и копулятивные органы Cytaea semengohi sp.n. (32-35), C. sepakuensis sp.n. (36-37); Donoessus striatus (38-39), Euophrys wanyan (40); 32-33 - общий вид, сверху и сбоку; 34-35 - пальпа, снизу и сбоку; 36, 38 - эпигина; 37, 39-40 — внутренние структуры эпигины. 32-39 - Борнео; 40 - Суматра. 40 - по Pryszycski et al. [2012a]. 

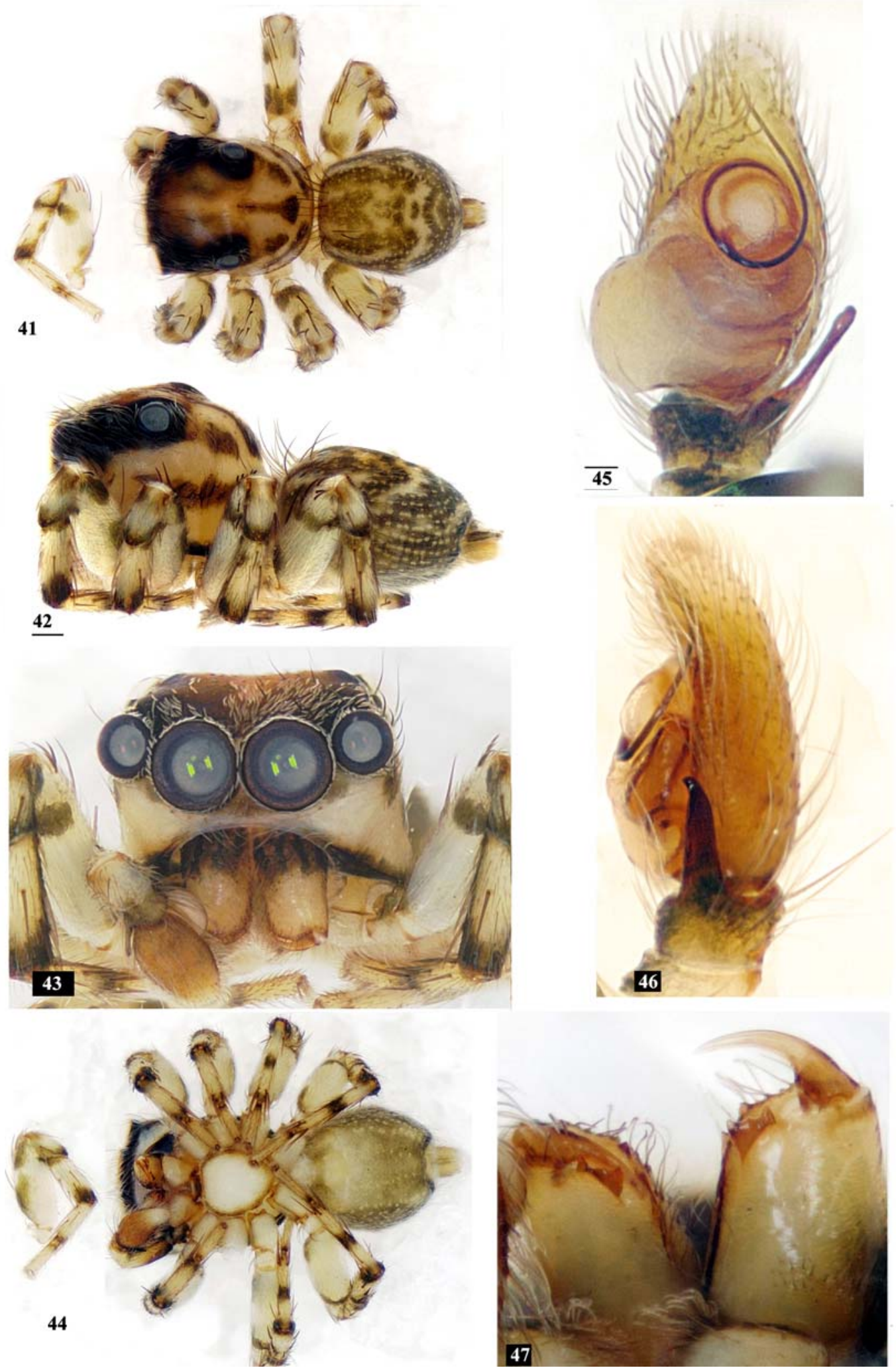

Figs 41-47. General appearance, palpus and cheliceral dentition of Cytaea trusmadii sp.n. (holotype) 41 - general appearance, dorsal views; 42 - lateral views; 43 - frontal views; 44 - ventral views, 45 - palpus ventrally; 46 — palpus laterally; 47 — cheliceral dentition. OPhotographs by P. Koomen.

Рис. 41-47. Общий вид, пальпа и вооружение хелицер Cytaea trusmadii sp.n. (голотип) 41 — общий вид, сверху; 42 - сбоку; 43 - спереди; 44 - снизу, 45 - пальпа снизу; 46 - пальпа сбоку; 47 - вооружение хелицер. ОФотографии Р. Koomen. 
dark, black dorsally, rims of lenses of eyes surrounded with single line of short, adpressed whitish setae. Chelicerae short, slender, white, with dark brown upper third, their inner posterior edge with bicuspid yellow tooth (in one chelicera there is an additional, third minute cusp), fang smooth (Figs 43, 47). Legs I-IV whitish, with tarsi yellowish, there are darkenings in the joint areas, tibiae and patellae with darker, blackish brown dorsal annuli (Figs 41-44). Palpi whitish, with cymbium dorsally fawn, except whitish tip and yellowish proximal half. Ventral surfaces of tibia and femur dark, there is broad blackish spot on distal end of tibia, ventrally. Tibial apophysis almost straight, with tip bent (Fig. 46). Palpal organ with tight, but broad loops of meandering spermophor duct and prominent prolateral bulge. Basal pad of embolus circular, embolus arising at 8 o'clock (Figs 45-46).

Female unknown.

DISTRIBUTION. Documented from Borneo: Sabah (Malaysia).

Donoessus striatus Simon, 1902

Figs 36-37.

\author{
D. s. Simon, 1902: $376\left(\sigma^{7}\right)$. \\ D. s.: Simon, 1902: $376\left(0^{7}\right)$. \\ D. s.: Żabka, 1988: 451, f. 84-86 $\left(\sigma^{7}\right)$ \\ D. s.: Prószyński \& Deeleman, 2012: 33-35, f 15-17 ( ( \\ MATERIAL. + , Borneo Isl.: W Sarawak: Semengoh Arbore-
} tum, upper trail, beating shrub, 27.03.1985 (D-R). CDML.

DIAGNOSIS. Epigyne and its internal structures resemble those of Donoessus kerinci Prószyński et Deeleman [2012: 34, f. 18-19] with regard to the shape of the two chambers in the divided spermatheca. However, in D. striatus the first chamber is elongate oval, and the sclerotized copulatory duct is distinctly longer (Fig. 37).

DESCRIPTION. Male (provisionally matched) see Prószyński \& Deeleman, 2012 [33-35, f 15-17].

Female. Detailed description of the body shape and color pattern not available. Color pattern of a female of Donoessus sp. is shown in photographs by Koomen [Prószyński, 2012] but the species identity has not been confirmed, due to lack of a picture of the spermatheca. Epigyne transverse oval, with white membranous 'window', partially constricted in the middle (Fig. 36), with translucent pair of semi arches of copulatory ducts and a pair of double chambered spermathecae. When viewed mounted on a microscopic slide the ducts are relatively broad, with walls sclerotized along their entire length, there is a distinct scent gland opening at the mid-length of the duct. Spermatheca consists of two chambers, the first is elongate oval, with an indistinct constriction (Fig. 37); the second is elongate oval joined to the first by a short, broad connection, it is positioned diagonally, turned $135^{\circ}$, and partially overlaps the first chamber on its ventral side.

REMARKS. There is a striking similarity of the internal structure of the epigyne to that seen in $D$. kerinci [Prószyński \& Deeleman, 2012: 34, f. 18-19] from Sumatra, the only other species in the genus Do- noessus for which the internal epigyne structure is known. We match this female specimen provisionally with $D$. striatus, the only species of that genus known from Borneo, however, from the distant part of the island. Because of the rarity of that type of spermatheca, which positively identifies the genus, this female specimen deserves publication, but a shortage of data prevents description of it as a new species.

DISTRIBUTION. Documented from Borneo: Sarawak, Semengoh (Malaysia), male was reported previously from Sabah: Danum Valley (Malaysia).

\section{Gen. Echeclus Thorell, 1890}

Type species E. concinnus Thorell, 1890 from Malaysia: Pinang

REMARK. Monotypic genus known until now from single $\sigma^{7}$ specimen kept in the Museo Civico di Storia Naturale in Genoa [Prószyński, 1984: 36, f. unnumbered].

\section{Echeclus sokoli sp.n.}

Figs 25-31.

MATERIAL. Holotype $\sigma^{\top}$, allotype,+ 1 paratype + , Borneo Isl.: W Sarawak, Matang Res., $1800 \mathrm{ft}$. (D-R). CDML.

ETYMOLOGY. Named after our collaborator (since 2003) and a friend, programmer Marek Sokół.

REMARKS. Male placed in the genus Echeclus due to palpus resembling that of the type species, especially the structure of the bulbus and tibial apophysis. Externally, the epigyne appears rather non-descript and of average shape, but its internal structure does not resemble any known species. The structure of the genital organs does not fit in any subfamily delimited at present.

DIAGNOSIS. Palpus resembles closely that of $E$. concinnus, the type species of the genus [Prószyński, 1984: 36. f. unnumbered], but differs by the embolus resembling a screwed, narrow plate, and an oval tibial apophysis with a shallow anterior notch Fig. 27). The internal structure of the epigyne is unique.

DESCRIPTION. Male. Stout spider, body 5.28 long, carapace high, as long as abdomen (Fig. 25). Eyefield occupies half the length of the carapace, slightly narrowing posteriorly, posterior slope of carapace steep. Sides of carapace dark, dorsum light with scattered darker setae. Abdomen high, with smooth, sclerotized oval dorsal plate, dark with small, irregular lighter dots. Sides and posterior part of abdomen gray, finely wrinkled. Legs stout, legs I slightly longer than remaining. Palpus with femur broad, bent (Fig. 28), tibia short and broad, tibial apophysis expanded into ovoid plate with semicircular anterior notch. Posterior part of bulbus almost rectangular, median and anterior part expanded laterally, two times broader (Fig. 27). There are two darker, sclerotized tegular plates, separated anteriorly by broad, white space, but posteriorly by a thin white line. Anterior edge of bulbus sclerotized, semicircular, with sharp pointed process. Embolus forms 
of a broad, screwed plate, touching prominent loop of sperm duct (Fig. 29).

Measurements (approximate, in $\mathrm{mm}$ ): length of carapace 2.64 , length of abdomen 2.64, length of eyefield 1.32 , width of eyefield at eyes I 1.32, width of eyefield at eyes III 1.12 .

DISTRIBUTION. Documented from Borneo: Sarawak (Malaysia).

Remarks on the subfamily Euophryinae Prószyński, 1976

Type genus Euophrys C.L. Koch, 1834.

REMARKS. The delimitation (and hence species included) of the subfamily Euophryinae requires revision. Taxa of the subfamily level, or higher, are delimited by characters common to all species assigned, and exclusive to them. Such a character for males of $>841$ nominal species of Euophryinae, occurring on all continents (219 nominal species in Asia, only 19 were reported from Borneo), is the embolus twisted into a spiral atop of the bulbus. It is a striking character, easily visible at a first glance of the palpal organ. For Maddison [Maddison \& Hedin, 2003: 540, 542], the plane in which the spiral of the embolus is oriented, perpendicular or parallel to the main axis of the palpus, is an important difference. But that plane is diverse within a larger group of genera (see for instance Ballus chalybeius (Walckenaer, 1802), Servaea vestita (L. Koch, 1879), Gambaquezonia itimana Barrion et Litsinger, 1995 [Prószyński, 2012]), and there are intermediate forms in several genera. There is some variation in the length of the embolus among species of the same genus, such that the spiral of the embolus can form a full circle, half circle, or even a quarter of a circle, and the coils of the spiral may be tight or loose. Also, the meandering spermophor vessel, forming a large and striking transverse loop in the mid length of the bulbus is diagnostic, but in a few species and genera, it is atypical (semicircular in Gambaquezonia [Edwards, 2009, figs 4-5], almost straight in Ballus chalybeius [Proszyñski, 2012]. The consequent application of the 'spiral embolus concept' results in the inclusion into Euophryinae of some genera previously placed in other taxa - in particular Tomomingii Szüts et Scharff, 2009 from Hisponinae and all genera of the subfamily Ballinae.

There are no such widespread diagnostic characters for females in Euophryinae, the most useful characters - internal structures of the epigyne differ widely: from simple globular spermathecae and short, straight copulatory ducts, to structures that are very complicated indeed. Body shape, cheliceral dentition, leg spination and setae coverage are widely diversified in Euophryinae, but could be useful for subdivision of these spiders into genera.

Previous classifications were based on different concepts. Simon's system (1901-1903) was based on cheliceral dentition, eye positions and shape of the eyefield, body shape, setae arrangements and spination patterns. Such characters vary in uncorrelated way. As a result, genera with spiral emboli were segregated into 12 groups of genera, mixed up with genera having nonspiral emboli and frequently grouped into improbable taxa. Simon paid little attention to genital organs and their illustrations constitute only a fraction among 1122 drawings in his book [Simon, 1901-1903]. The Euophryinae in the current sense contains genera separated from the following groups recognized by Simon. From the Pluridentati section: Balleae [op. cit.: 481]. From the Unidentati section: Chalcoscirteae [op. cit.: 572], Coccorchesteae [op. cit.: 612], Evophrydeae [op. cit.: 568], Saitideae [op. cit.: 558], Thianieae [op. cit.: 586], Zenodoreae [op. cit.: 648]. From the Fissidentati section [op. cit.: 756]: Athameae [op. cit.: 534], Cytaeae [op. cit.: 810], Laufeiae [op. cit.: 822], Spilargeae [op. cit.: 762-767], Emathidae [op. cit.: 804].

Simon's division was synthesized by Petrunkevitch [1928], who elevated groups of genera to the ranks of subfamilies, retaining their characters. These subfamilies are listed by Bonnet [1959: 5052-5054]; Roewer [1954] went further, arranging genera by these subfamilies in his "Katalog" (with the rather inconvenient result of needing to search for every genus in the Species Index). The possibility of alternative interpretations of the similarities between 885 nominal species of Euophryinae was demonstrated by comparative illustrations of the palpi and epigynes by Prószyński [1976, plates 11-24], further developed in the database [Prószyński, 1995-2012], the latter containing drawings of 567 species (of which 203 species have both sexes illustrated, with a further 364 species represented by drawings of one sex only). The quality of drawings available in the literature varies; to be fully convincing palpi and epigynes of all species should be illustrated in a comparable way.

Alternative subdivisions of the subfamily are very incomplete, so their merits are difficult to discuss. We can expect a more objective grouping of genera from gene sequencing studies [Madison \& Hedin, 2003; Madison \& Zhang, 2006; Madison et al., 2007, 2008], but the results are currently known only for some $2 \%$ of salticid species.

The name of the subfamily was proposed originally as Euophrydinae by Prószyński [1976], following Simon's group Evophrydea. Its amendment to Euophryinae was proposed by G.B. Edwards (in a private letter) after consultation with a Latin language professor $\mathrm{H}$. Don Cameron, University of Michigan.

\section{Gen. Euryattus Thorell, 1881}

Type species Euryattus porcellus Thorell, 1881 from New Guinea.

REMARKS. The genus as currently defined contains seven nominal species, of which four have diagnostic drawings for both sexes, one for one sex only, and two species have no drawings. The type of $E$. venustus (Doleschall, 1859) is lost, the original old drawing, reproduced here (Fig. 88), does not show 

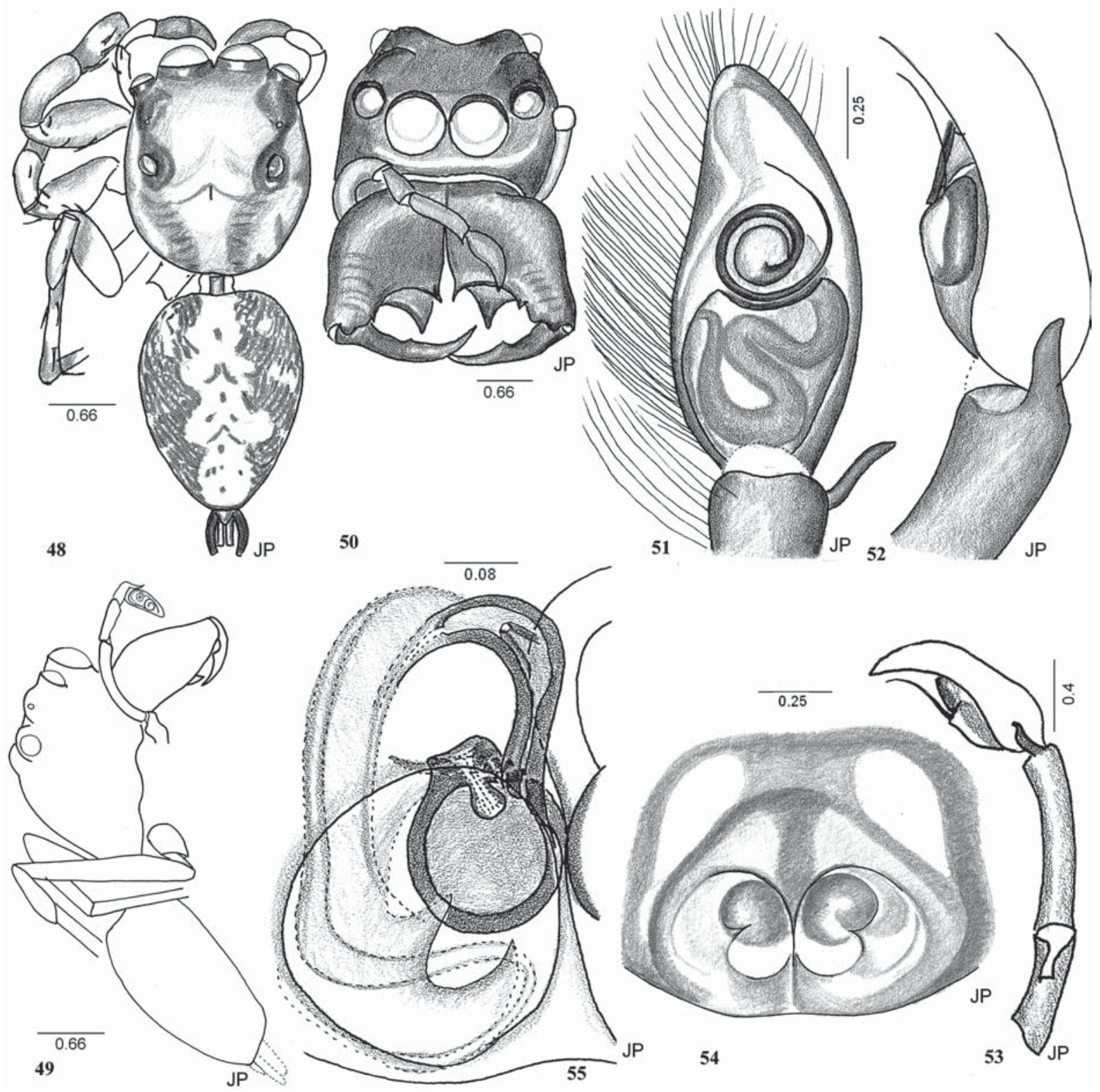

Figs 48-55. General appearance and copulatory organs of Euryattus kinabalusi sp.n. 48-49 - general appearance, dorsal and lateral views; 50 - face and chelicerae; 51-53 - palpus, ventral and lateral views; 54-55 - epigyne and its internal structures.

Рис. 48-55. Общий вид и копулятивные органы Euryattus kinabalusi sp.n. 48-49 - общий вид, сверху и сбоку; 50 — «лицо» и хелицеры; 51-53 - пальпа, снизу и сбоку; 54-55 - эигина и её внутренние структуры.

useful characters, so we cannot be sure that the interpretation of that species by Thorell [1878], based on a new specimen from Ambon (Fig. 87), was correct. Thorell labeled another specimen of that genus, from New Guinea, E. ventralis, but did not publish a description, which we rectify below. Similarities in the internal structures of the epigyne indicate closer relationships between Euryattus bleekeri (Doleschall, 1859) (Fig. 86), E. porcellus Thorell, 1881 (Fig. 85) and E. venustus (Doleschall, 1859) (Figs 87-88). The classification of the three new Bornean species described below is tentative. Transfer of Plotius curtus Simon, 1902 from Halmahera: Edkor [Prószyński, 1987: 78, 107, figs unnumbered; Żabka, 1988: 154, figs 91-92], the type species of the genus Plotius Simon, 1902, prompted Platnick [2011] to transfer to Euryattus the three other species of Plotius Simon, 1902. We object to this because the generic transfer of species not supported by diagnostic drawings, and never revised, can only increase nomenclatorical chaos. Therefore, we return temporarily to the original, unchanged combinations: Plotius breviusculus Simon, 1902, P. celebensis Merian, 1911, and P. leopoldi Roewer, 1938, pending revision of the types. 

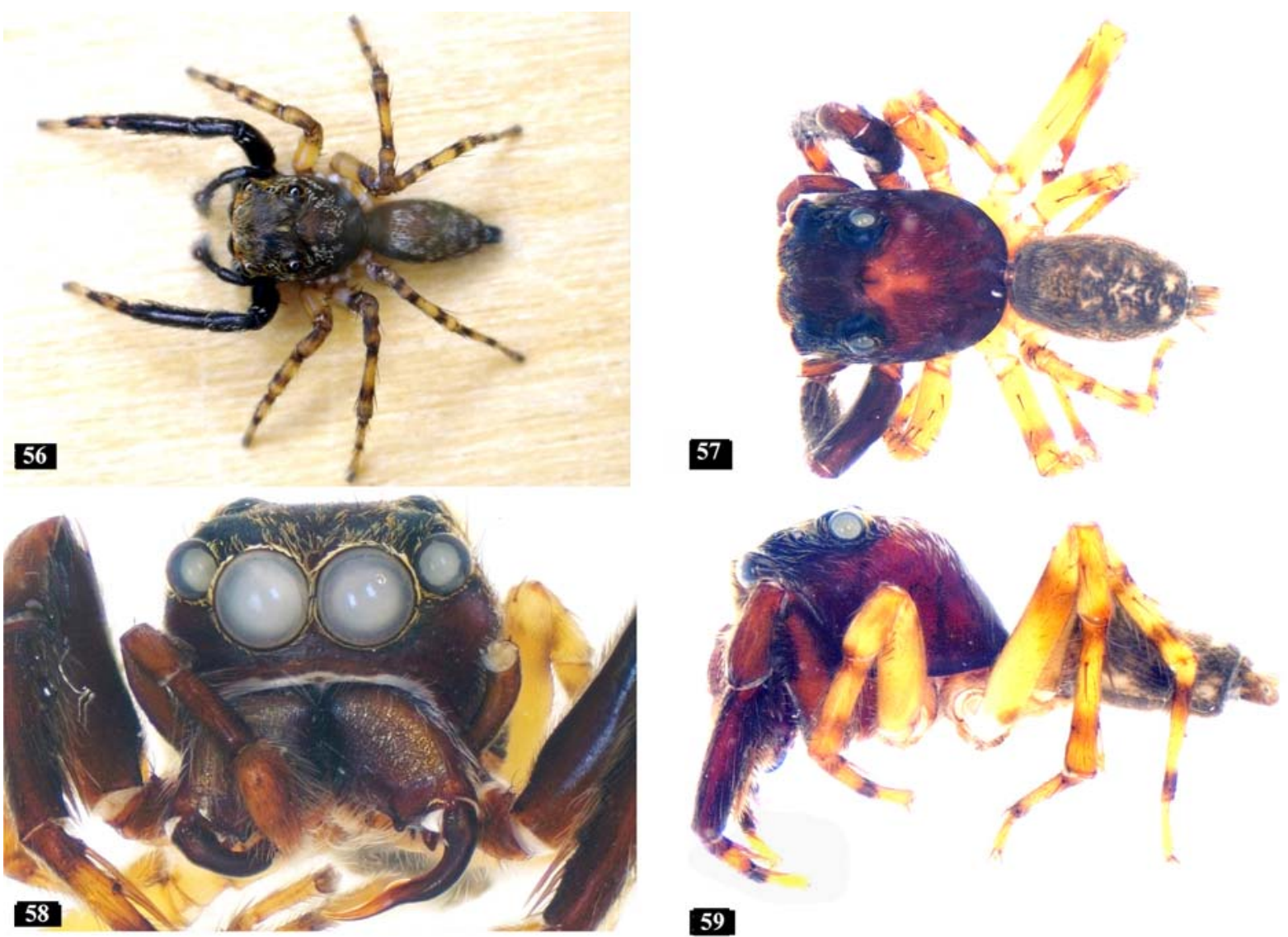

59
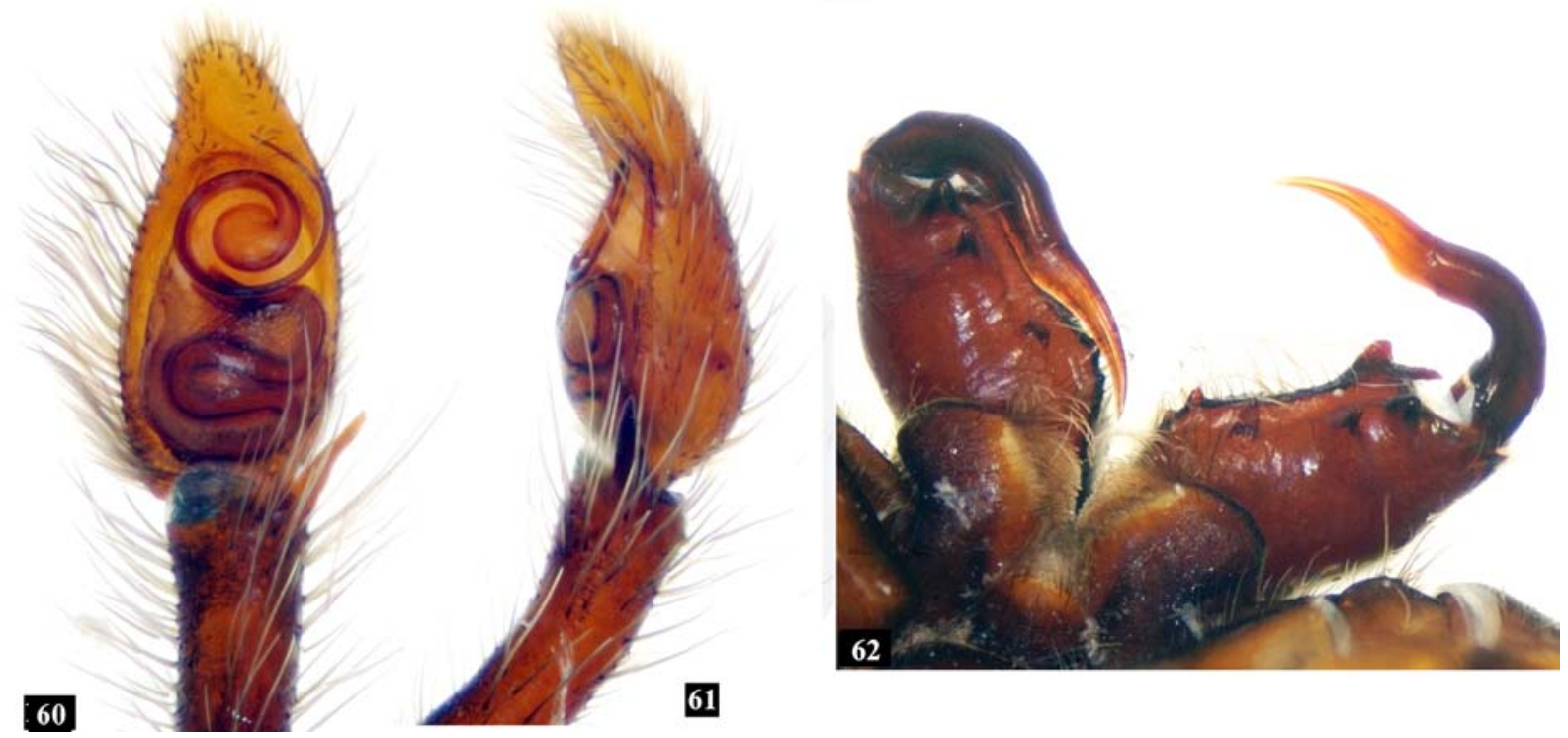

Figs 56-62. General appearance and copulatory organs of male Euryattus koomeni sp.n. 56-57 -dorsal views; 58 - face and chelicerae; 59 - lateral view; 60-61 - palpus, ventral and lateral views; 62 - cheliceral dentition. 56 - alive specimen; 57-62 preserved specimens. (P) Photographs by P. Koomen.

Рис. 56-62. Общий вид копулятивные органы самца Euryattus koomeni sp.n. 56-57 - сверху; 58 - «лицо» и хелицеры; 59 сбоку; 60-61 - пальпа, снизу и сбоку; 62 - вооружение хелицер; 56 - в природе; 57-62 - фиксированный экземпляр. (С)Фотографии Р. Koomen.

DESCRIPTION. Males. Medium-sized spiders with robust appearance, carapace high and broad, indistinctly shorter than abdomen (Figs 48, 56-57). Eyefield occupies half the length of the carapace, rectangu- lar, slightly sloping forwards. Thoracic part rounded in profile, without flat part, its posterior slope gentle (Figs 49, 59). Abdomen indistinctly longer than carapace, oval, pointed posteriorly. Chelicerae robust, diverging, 
with long fang and three robust, spaced teeth on inner posterior margin. Anterior walls of chelicerae together form a shallow, concave groove. Diameter of anterior median eyes one and half times larger than that of anterior laterals (Figs 50, 58). Clypeus low. Segments of palpus long, especially tibia. Palpal organ typical for Euophryinae. Coil of embolus in front of tegulum, in the same plane and as broad, forms one and half turns around its base. There is usually a curious broadening of the embolus near the tip, possibly functioning to plug the female copulatory duct, when broken off after insemination.

Female. General appearance of the body resembles male (Figs 63-66, 70-73, 79-80). Chelicerae are robust, but in contrast to males have only a single tooth on inner posterior margin. Epigyne oval with a pair of oval membranous 'windows' (Figs 69, 76) in the posterior half, in some species part of the 'window' is obliterated by a sclerotized brown plate and the membranous area reduced to a fraction of the surface of the 'window' (Figs 54, 67, 74, 77, 81). 'Windows' are separated by a low septum, which differs in length and width between species, in addition to the proportions to the whole epigyne. Copulatory openings are indistinct, followed by an initial arch of the copulatory duct, sometimes expanded into a broad chamber, running to the anterior end of the epigyne. From the anterior bend the copulatory duct runs back, joining spermatheca either directly, or via a small transverse arching part (Figs 55, 67, 74-77).

DISTRIBUTION. Genus reported from Australia, various parts of the Malay Archipelago and New Guinea, report from Sri Lanka is not confirmed.

\section{Euryattus kinabalus sp.n.}

Figs 48-55.

MATERIAL. Holotype ${ }^{\circ}$, allotype $\sigma^{\top}$, Borneo Isl.: W Sabah: National Park Kinabalu, 1560 m, 21-26.07.1980 (D-R). CDML.

ETYMOLOGY. Specific name adjective derived from the Mt. Kinabalu and National Park Kinabalu, in Sabah, Borneo.

DIAGNOSIS. Male differs from E. koomeni sp.n. by having a distinctly larger posterior spermophor loop and having the median spermophor loop shifted anteriorly (Fig. 51). Female differs from E. koomeni sp.n. (below) by the sclerotized surface of the 'windows', with only small circular membrane 'windows' medially touching the septum.

DESCRIPTION. Male. Carapace with lighter eyefield and medial area of thoracic part, separated from similar colored lateral upper sides by two darker streaks. Abdominal pattern in preserved specimen includes medial broad streak, broadened in four areas and separated by partial constrictions (Fig. 48). White line across clypeus, just below eyes I (Fig. 50). Legs light with darker annulations. Palpi long, light with darker cymbium. Cymbium about one quarter times longer than bulbus and coil of embolus about one third broader than palpal tibia (Figs 51-53).
Measurements (approximate): length of carapace 2.3 , length of eyefield 1.15 , width of eyefield at eyes I 1.8 , width of eyefield at eyes III 1.5 , width of carapace 2 , height of carapace 1.3 , length of abdomen 2.3 , width of abdomen 1.8, height of abdomen 1.05.

Female holotype. Description of external appearance not available. White membrane of epigynal 'windows' restricted in size, located close to septum, in the mid-length of epigyne (Fig. 54). Spermathecae globular, small, descending part of the copulatory duct sclerotized, with small cone of the scent gland opening barely visible on the dark background (Fig. 55). Ascending, anterior part of the copulatory duct not sclerotized, copulatory opening located in the middle of the 'window'.

DISTRIBUTION. Documented from Borneo: Sabah (Malaysia).

\section{Euryattus koomeni sp.n.}

Figs 56-69.

MATERIAL. Holotype ${ }^{+}$, allotype $\sigma^{\top}$, Borneo Isl.: Sabah: SukauBukit Tomanggong Besar, $5^{\circ} 31.033^{\prime} \mathrm{N} 118^{\circ} 18.36^{\prime} \mathrm{E}$, some primary vegetation on limestone outcrop, in oil palm estate, 31.03.2003 (leg. Suhan Sukumaran \& P. Koomen). Photo P. Koomen. BCPK.

ETYMOLOGY. Named for Peter Koomen, creator of the exceptional 140 plates of photo-documentation of 47 species of Salticidae from Borneo displayed in Prószyński [2012].

DIAGNOSIS. Male palpus differs from that in $E$. porcellus [Prószyński, 1984: 45, f. unnumbered] by having a longer bulbus and a greater diameter of the embolus coil, and a distinctly more compressed and wider median loop of the spermophore. Female differs by the median location of the spermathecae, and by the sclerotized part of the copulatory duct running anteriorly, not transversally (Fig. 68).

DESCRIPTION. Male allotype. Body blackish brown with faint spots of sparse whitish adpressed setae and scales, those on eyefield are slightly denser, with addition of some yellow anteriorly (Fig. 56). The coloration of the preserved specimen is reduced to dark brown, setae and scales are inconspicuous and largely invisible, abdomen color reduced to dark gray, with pattern of post-mortem light, non-pigmented spots (Fig. 57). Face almost black, with clypeus and sides dark brown. Eyes I surrounded by upright scales, whitish with faint yellowish shade. Diameter of anterior lateral eyes about half those of the anterior median, and aligned along upper part of the latter. Clypeus bald, delimited ventrally by whitish membrane, with a few whitish setae (Fig. 58). Chelicerae dark, robust, slightly diverging, with long, waving, basally black fang. Inner anterior margin with a single large but blunt tooth, followed at a distance by two smaller ones; three large, widely spaced teeth on posterior margin (Fig. 62). Legs I with femur, patella and tibia black and light reflecting, with a few inconspicuous whitish scales and setae, metatarsus and tarsus yellow, with black ring proximally. Legs II-IV dark yellow, with black rings. 

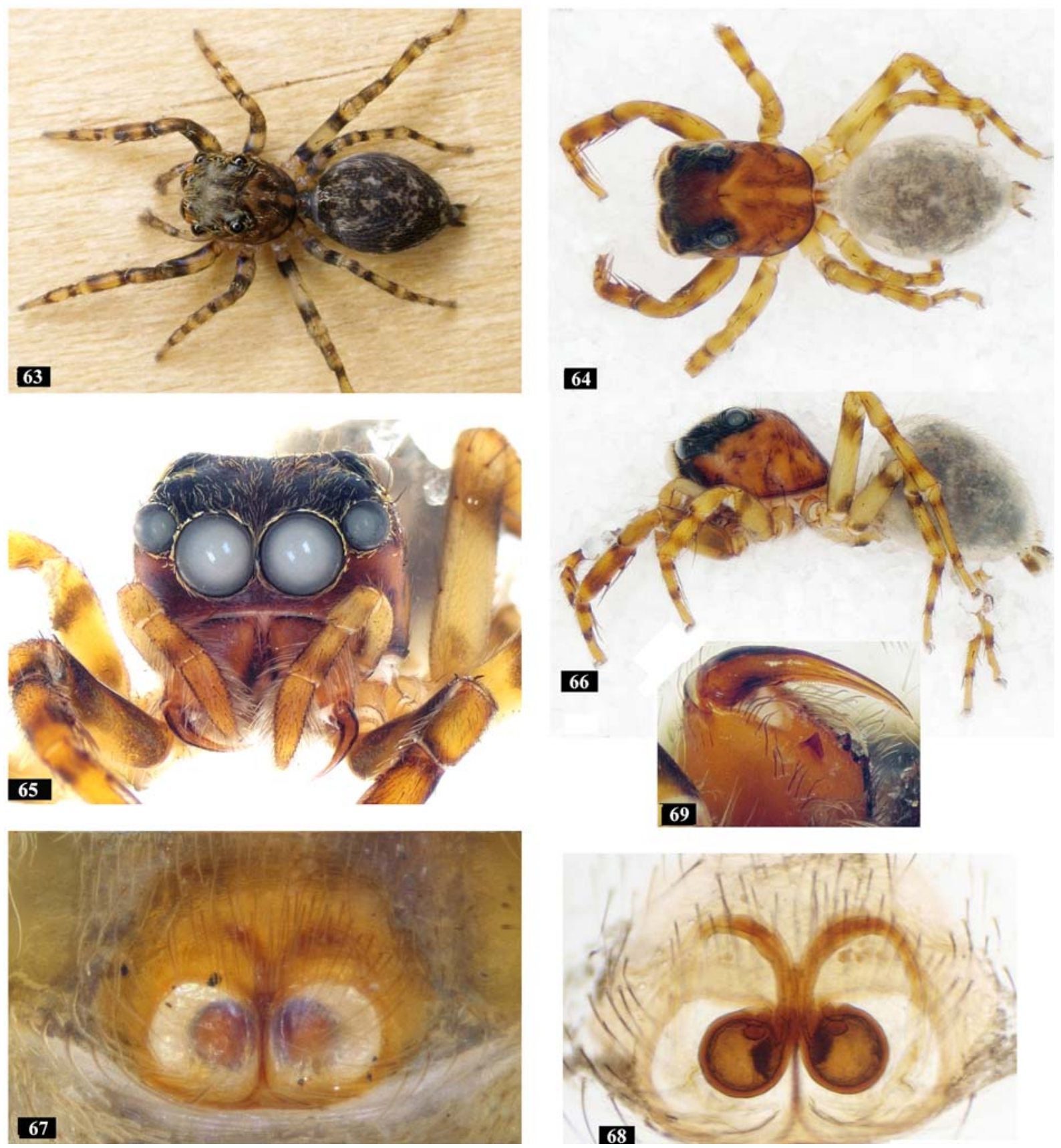

Figs 63-69. General appearance and copulatory organs of female Euryattus koomeni sp.n. 63-64 - general appearance, dorsal views; 65 - frontal view; 66 - lateral view; 67-68 - epigyne and its internal structures; 69 - cheliceral dentition. 63 - alive specimen; 64 69 - preserved specimen. OPhotographs by P. Koomen.

Рис. 63-69. Общий вид и копулятивные органы самки Euryattus koomeni sp.n. 63-64 - общий вид, сверху; 65 - спереди; 66 - сбоку; 67-68 - эигина и её внутренние структуры; 69 - вооружение хелицер. 63 - в природе; 64-69 - фиксированный экземпляр. СФотографии Р. Koomen.

In the preserved specimen black parts of legs are faded to dark brown, yellow areas are lighter yellow (Figs 56, 59). Palpi black, in preserved specimens brown, with whitish and gray setae on cymbium and tibia. Palpal organ long, about one and half times broader than tibia. Bulbus with meandering spermophore duct, forming broad, but tight loops. Diameter of loop of embolus as long as bulbus, relatively loose, encircling base of em- bolus, embolus a little extended beyond the loop (Fig. 60). Tibial apophysis narrow, its length is half the length of the bulbus (Fig. 61).

Measurements: carapace length 3.0, carapace width 2.3, abdomen length 2.3, abdomen width 1.3.

Female holotype. Appearance of fresh specimen, comparable to male, with legs I shorter than legs III. All legs dark yellow with blackish rings (Fig. 63). The 

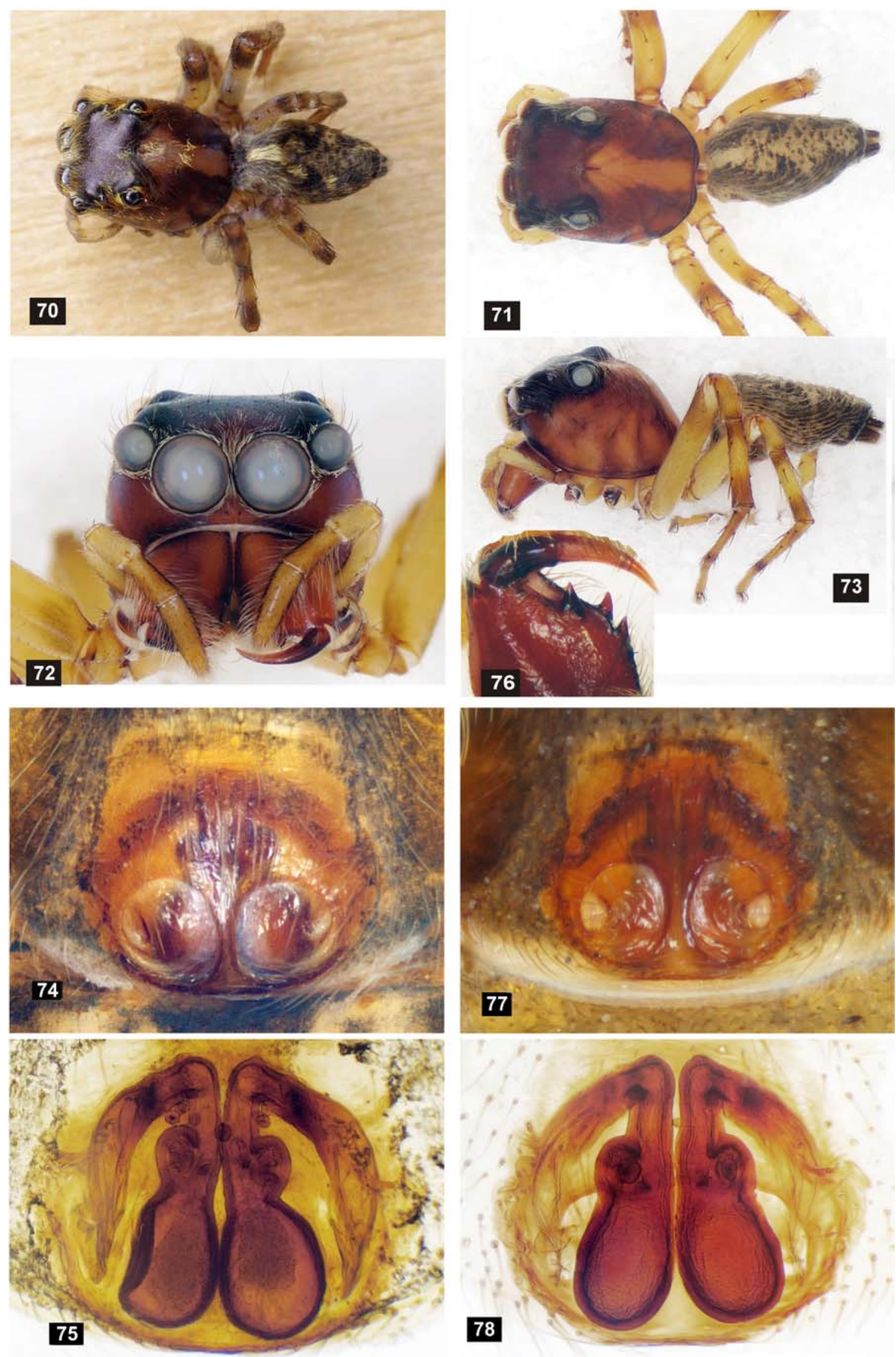
preserved specimen is much lighter, with abdomen macerated in part, light gray, legs yellow with light brownish rings (Figs 64-69). Face brown (Fig. 65), with eyefield blackish brown, chelicerae less robust than in male, brown, fang shorter and not wavy, a single tooth on the posterior margin and three smaller teeth on the anterior margin of the chelicerae (Fig. 69). Palpi and legs I yellow, grayish brown annulated (Fig. 63, 66). Epigyne with 'windows' round and large, membranous and not sclerotized, separated by narrow septum (Fig. 67). Spermathecae round, located at the septum in anterior part of the 'window' (Fig. 68). Copulatory opening almost invisible, at the center of each 'window', distal part of copulatory duct membranous and barely discernible, become sclerotized in front of the window, where duct forms a broad arch, before joining spermatheca.

Measurements: carapace length 2.5, carapace width 1.9, abdomen length 2.8, abdomen width 1.4.

DISTRIBUTION. Documented from Borneo: Sabah (Malaysia).

\section{Euryattus pengi sp.n.}

Figs $70-82$.

MATERIAL. Holotype + , Borneo Isl.: E Sabah, Danum Valley Field Centre, lowland primary forest, 6-16.05.1991 (D-R). CDML. Paratypes: + , Borneo Isl.: E Sabah, Danum Valley Conservation Area, along 'nature trail' between $4^{\circ} 57.45^{\prime} \mathrm{N} 117^{\circ} 48.45^{\prime} \mathrm{E}$ and $4^{\circ} 57.55^{\prime} \mathrm{N} 117^{\circ} 48.55^{\prime} \mathrm{E}$, alt. $160-170 \mathrm{~m}, 13.04 .2003$ (leg. Suhan Sukumaran \& P. Koomen). BCPK. + , Borneo Isl.: E Sabah: Sukau village area, around lodge, $5^{\circ} 30.94^{\prime} \mathrm{N} 118^{\circ} 18.122^{\prime} \mathrm{E}$, alt. $0 \mathrm{~m}$, hand catch, 2.04.2003 (leg. Suhan Sukumaran \& P. Koomen). BCPK.

ETYMOLOGY. Species named in honor of Dr. Xianjin Peng, prominent Chinese arachnologist, authority on Salticidae of China, author and co-author of 44 publications on Salticidae.

DIAGNOSIS. Differs from E. kinabalus sp.n. by the lateral location of the small, white membranous area on the sclerotized 'windows' of the epigyne (Figs 74, 77, 81 ) and the larger, oval spermatheca, oriented longitudinally and with a distinct bulge at the junction of the copulatory duct with the spermatheca (Figs 75, 78, 82).

DESCRIPTION. Male unknown.

Female. Medium-sized spider (about $6 \mathrm{~mm}$ long) of average shape and proportions (Figs 71-73, 79). Fresh specimen (Fig. 70) blackish brown with contrasting spots of white scales, longer preserved specimens are lighter brown, with more lighter spots, white scales are invisible (Figs 64-69). Carapace with broad light streak along thoracic part, spots on the abdomen are arranged into longitudinal streak consisting of three diamondlike clusters. Legs light with darker rings. Legs III longest. Carapace high with limited flat area behind eyes III and long thoracic slope (Figs 73, 80). Epigyne 'windows' covered by sclerotized brown plate, with only small marginal sector remaining membranous and white (Figs 74, 77, 81). Ascending part of the copulatory duct runs forward from the lateral area of the 'window', sclerotized and relatively broad, anteriorly with a lighter area densely dotted, possibly finely perforated. Passage into descending part of the copulatory duct under sharp angle, with very small opening of the scent gland armature at the top. Descending part of the duct runs straight, medially, broadened by prominent bulge where it joins the spermatheca (Figs 75, 78, 82).

Measurements (approximate, in $\mathrm{mm}$ ): length of carapace 3.0, length of eyefield 1.5, width of eyefield at eyes I 2.2, width of eyefield at eyes III 2.0, width of carapace 2.3 , height of carapace 2.0, length of abdomen 3.3, width of abdomen 2.2.

NOTE. There are minor differences between specimens from Danum Valley and Sukau in some parts of the copulatory organs, e.g. shape of the bend of the copulatory ducts and the width of the spermathecae, but the taxonomic significance of these differences is currently unknown.

DISTRIBUTION. Documented from Borneo: Sabah (Malaysia).

\section{Euryattus ventralis sp.n.}

Fig. 83-84.

Euryattus venustus ventralis: Prószyński, 1984c: 47, f. unnumbered ( $(+)$.

MATERIAL. Lectotype + Hasarius? venustus Thor. var. ventralis Thor., N Guinea: Andai (Doria) No. 1777b" "Prep. No. 6517". Thorell's coll. in Mus. Stockholm. NHRS

Comparative material. Euryattus venustus (Doleschall, 1859) "Hasarius venustus Dol. Amboina (Doria ded) No. 1777a" "Prep. No. 6511". Thorell's coll. in Mus. Stockholm. NHRS.

DIAGNOSIS. Epigyne differs from E. venustus (Fig. 87 ) by having a longer, but narrower copulatory entrance chamber, the copulatory ducts are distinctly longer and form a prominent bend before entering the spermatheca located at the posterior edge of the epigyne (Fig. 84).

DESCRIPTION. Male unknown. Female. No data on external appearance available. Epigyne transversely oval, incompletely divided by medial septum, passing into two incomplete arches at one quarter the length of the epigyne (Fig. 83). Internal structure originate from two broad and long, sclerotized entrance chambers, each with a groove running medially and becoming the copulatory duct. The duct forms a prominent bulge in front of spermatheca, then passes into thick-walled loop at about the mid length of spermatheca, and joins spermatheca anteriorly by another loop (Fig. 84). Spermatheca round, relatively small, located in the posterior third of epigyne.

Figs 70-78. General appearance and copulatory organs of female Euryattus pengi sp.n. 70-71 — general appearance, dorsal views; 72 - frontal view; 73 - lateral view; 76 - cheliceral dentition; 74, 77 - epigyne; 75, 78 - internal structures of epigyne. 70 - alive specimen; 64-69 - preserved specimens. 70-75 — from Danum Valley. 76-78 — from Sukau. CPhotographs by P. Koomen.

Рис. 70-78. Общий вид и копулятивные органы самки Euryattus pengi sp.n. 70-71 — общий вид, сверху; 72 - спереди; 73 сбоку; 76 - вооружение хелицер; 74, 77 - эпигина; 75, 78 - внутренние структуры эпигины. 70 - в природе; 64-69 фиксированные экземпляры. 70-75 - из Danum Valley. 76-78 - из Sukau. СФотографии P. Koomen. 


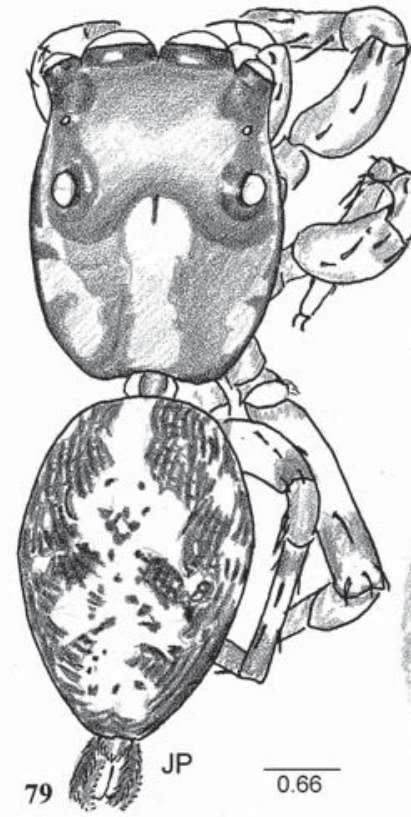

Euryattus pengi

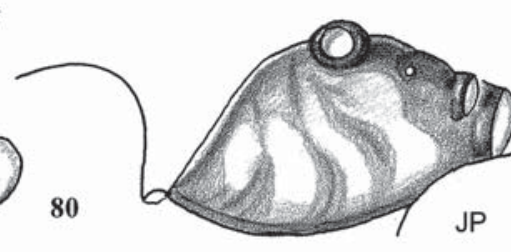

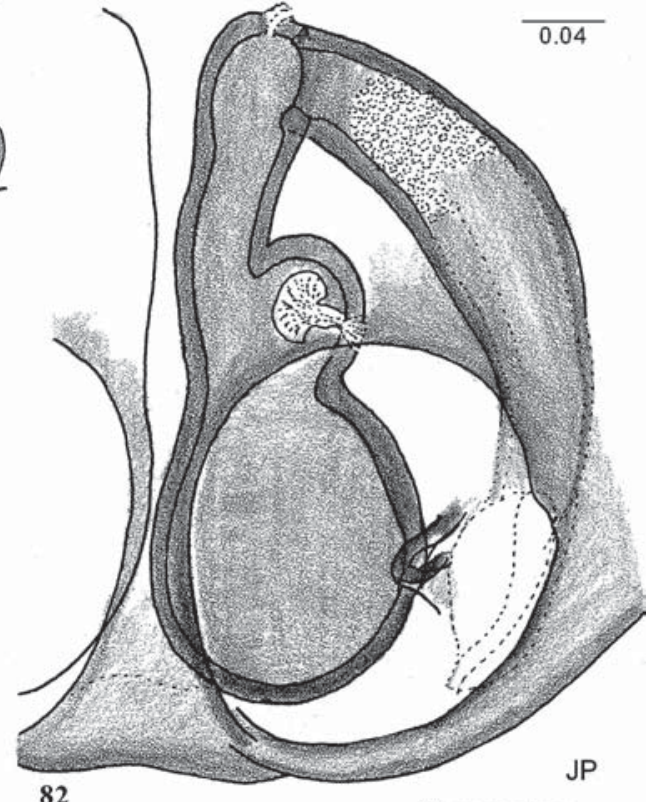

Euryattus pengi

E. venustus
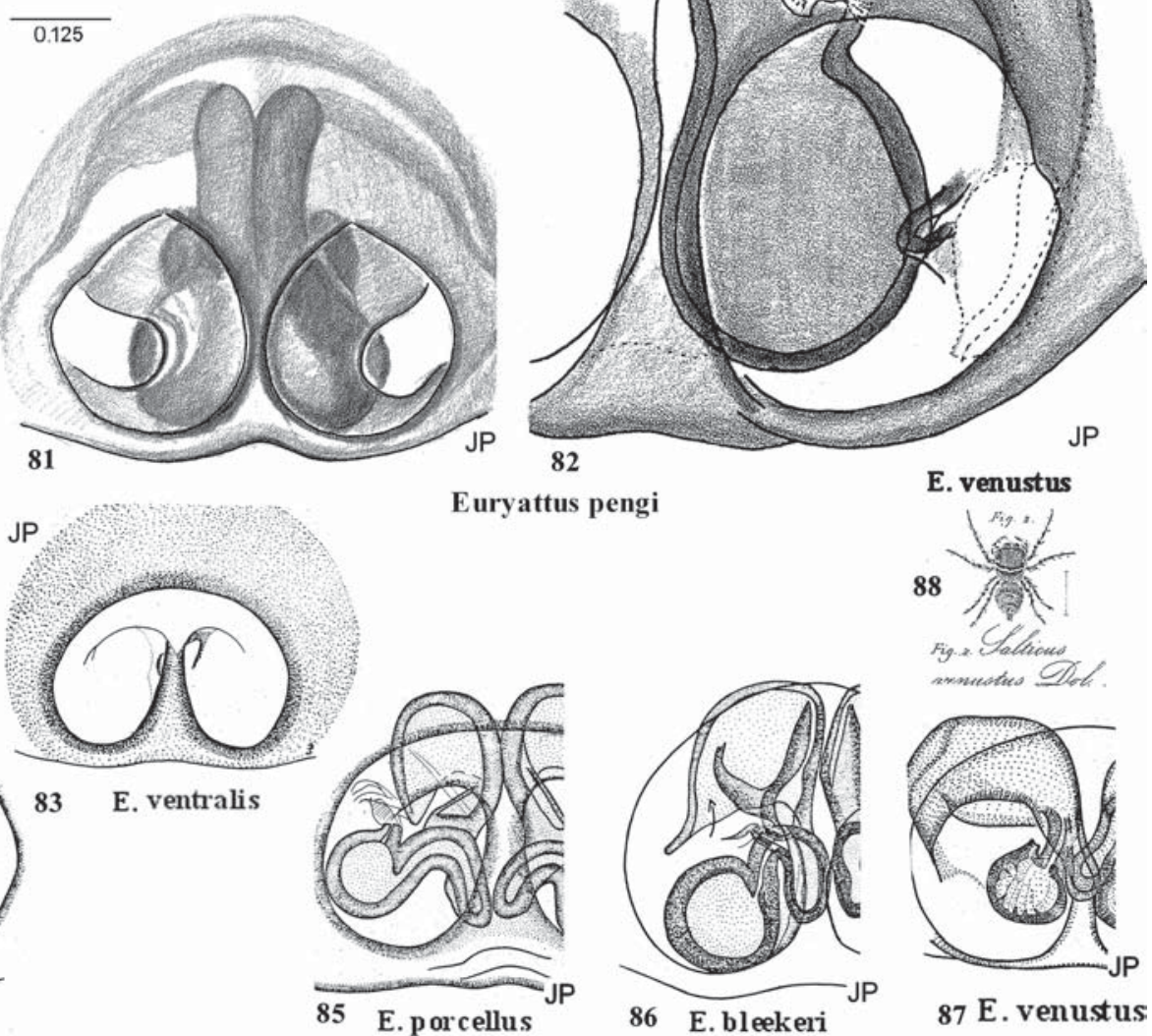

87 E. venustus

Figs 79-88. General appearance and copulatory organs of Euryattus bleekeri (86), E. pengi sp.n. (79-82), E. porcellus (85), E. ventralis sp.n. (83-84) and E. venustus (87-88). 79, 88 - general appearance, dorsal views; 80 - carapace; 81, 87 - epigyne; 82-86 internal structures of epigyne. 79-82 - from Borneo Isl.. 87-88 — from Java; 83-86 from N Guinea. 88 — after Doleschall [1859], 8387 - after Prószyński [1984].

Рис. 79-88. Общий вид и копулятивные органы Euryattus bleekeri (86), E. pengi sp.n. (79-82), E. porcellus (85), E. ventralis sp.n. (83-84) и E. venustus (87-88). 79, 88 - общий вид, сверху; 80 - карапакс; 81, 87 - эпигина; 82-86 - внутренние структуры эпигины. 79-82 - Борнео. 87-88 - Ява; 83-86 - Новая Гвинея. 88 — по Doleschall [1859], 83-87 — по Prószyński [1984].

REMARKS. This is a complementary description of the undescribed species from New Guinea, found in Thorell's collection in Stockholm, identified and labeled by Thorell himself as a new variety "ventralis" of "Hasarius" venustus (Doleschall, 1859) (Figs 8788), apparently a good species. Another specimen, labeled Plexippus venustus ventralis (not examined) is kept in the Museo Civico di Storia Naturale in Genoa [Prószyński, 1971]. However, the interpretation of "Hasarius" venustus by Thorell, reported from Indonesia: Ambon, may be questionable because the holotype of that species had been lost prior to Thorell's work and the original, very small drawing in the paper of Doleshall (Fig. 88), does not particularly resemble Euryattus. Future students revising that species should be warned that re-examination of the epigyne, shown in Fig. 84, which is mounted in Canada balsam, may require dissolving the balsam, re-staining and preservation in alcohol.

DISTRIBUTION. Documented from N Guinea: Andai.

Gen. Onomastus Simon, 1900

Type species: Onomastus nigricaudus Simon, 1900.

DESCRIPTION. Small spiders, not resembling jumping spiders, except by their large anterior median eyes. Eyes arranged in four rows, with the anterior laterals located behind the anterior medians, aligned slightly above dorsal rims of the latter. Eyes of the 


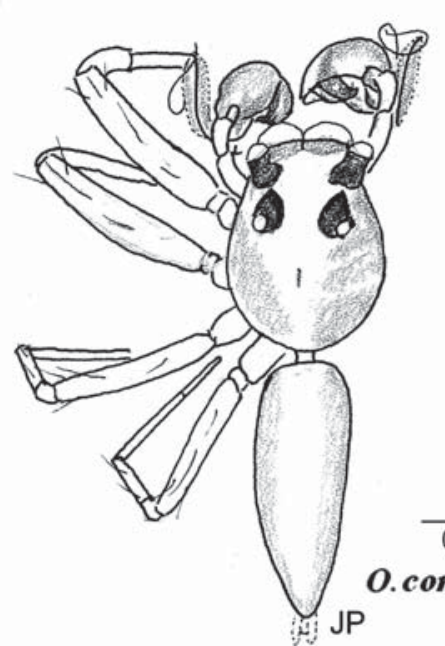

89

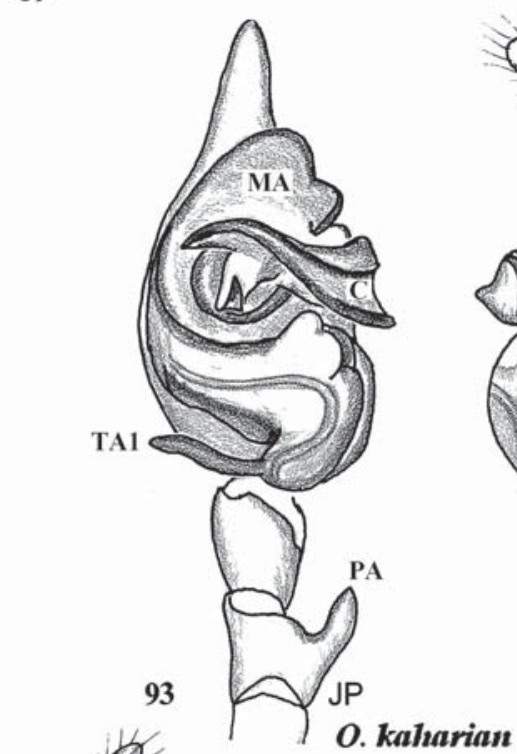

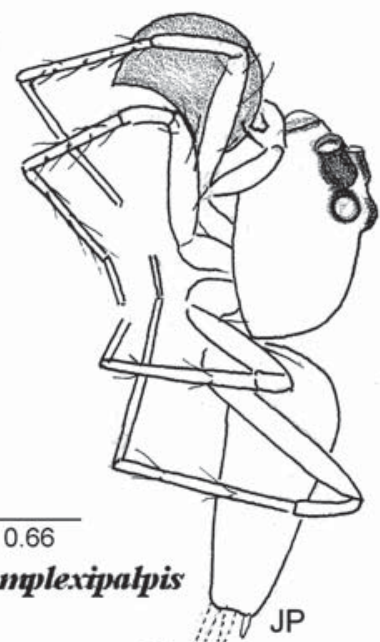

90

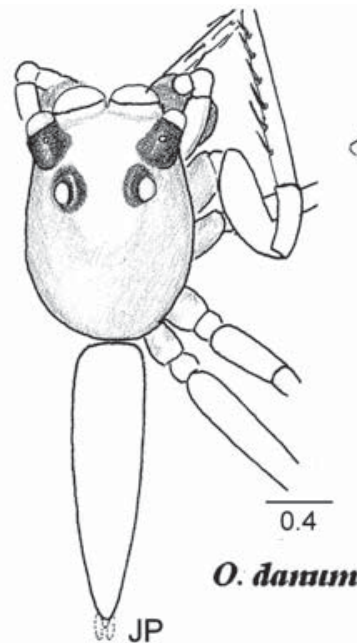

91

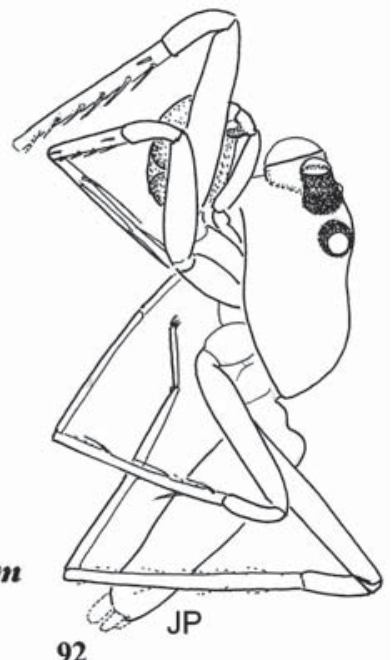

92
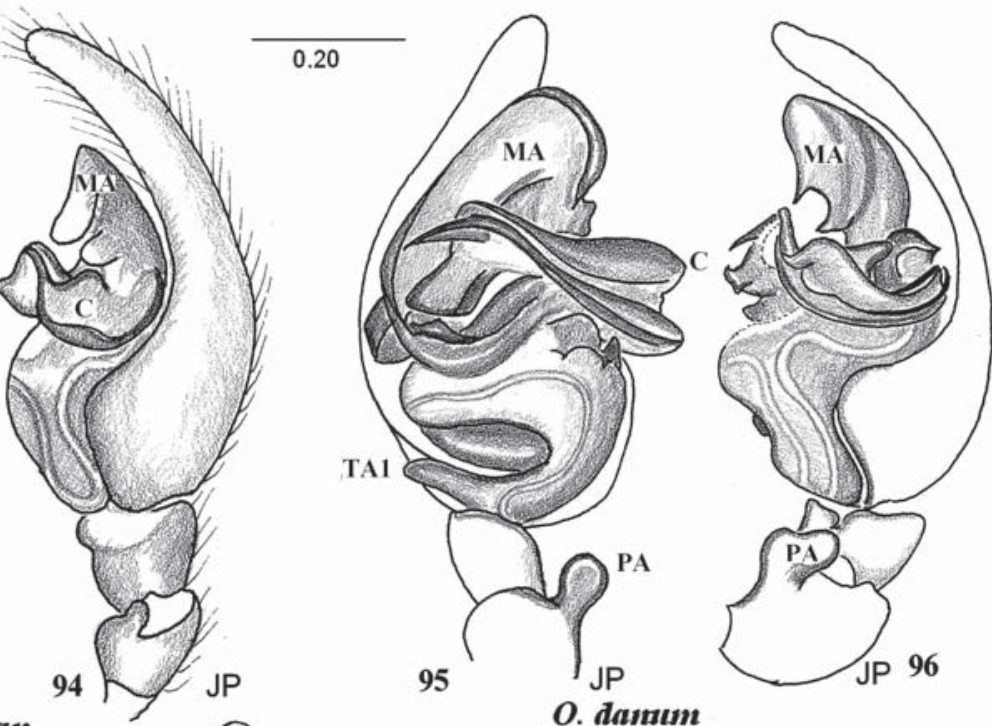

O. damum

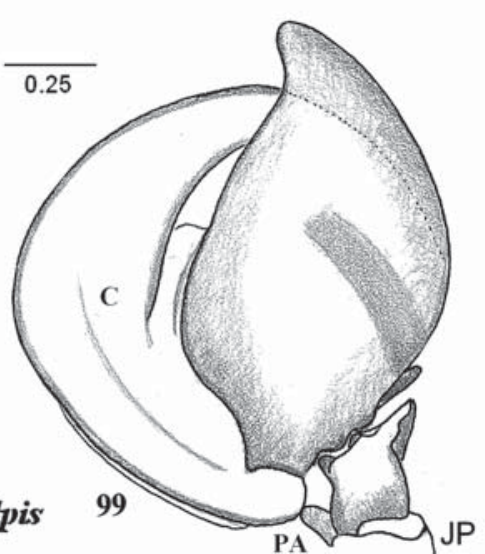

Figs 89-99. Comparison of general appearance and palpus in males of Onomastus complexipalpis (89-90, 97-99), O. danum sp.n. (91-92, 95-96) and $O$. kaharian (93-94). 89-92 - general appearance dorsal and lateral views; 93-99 - palps, ventral and lateral views. Details of palpus: $\mathrm{C}$ - conductor, E - embolus, MA — median apophysis, PA — patellar apophysis, TA1 — tegular apophysis 1.

Рис. 89-99. Сравнение общего вида и пальпы самцов Onomastus complexipalpis (89-90, 97-99), O. danum sp.n. (91-92, 95-96) и O. kaharian (93-94). 89-92 - общий вид, сверху и сбоку; 93-99 - пальпа, снизу и сбоку. Детали пальпы: С — кондуктор, Е эмболюс, МА — медиальный отросток, РА — отросток колена, ТА1 — тегулярный отросток 1. 


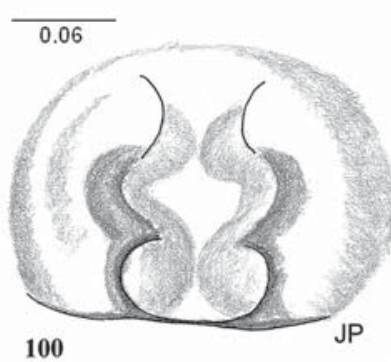

O. Kaharian

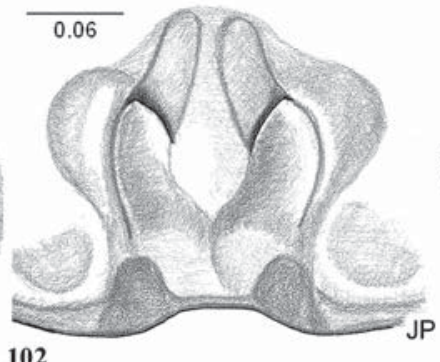

O. danแm

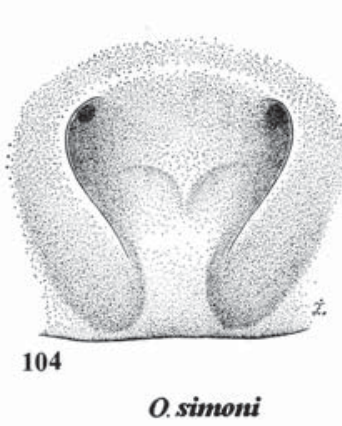

O. simoni
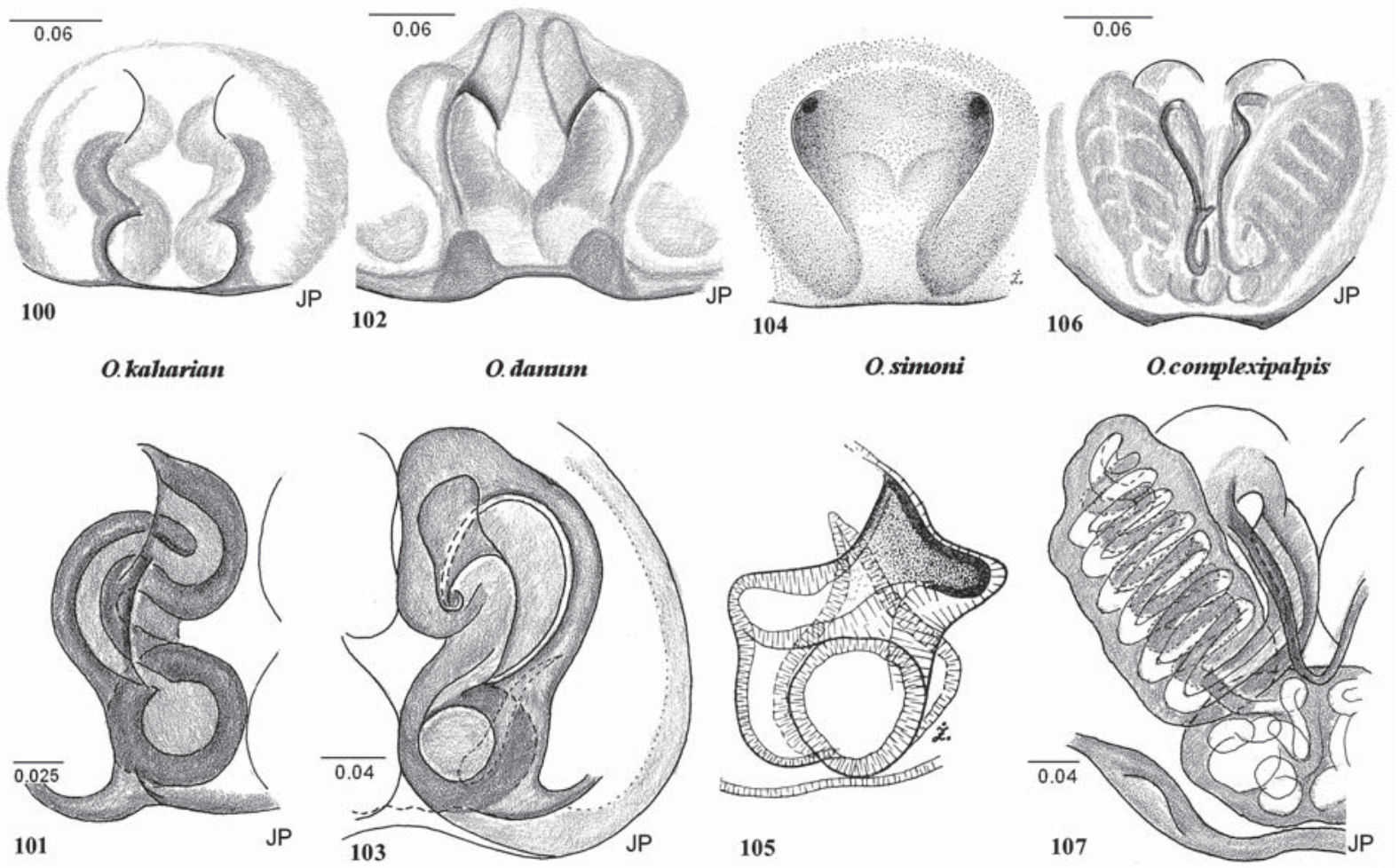

Figs 100-107. Epigyne in Onomastus complexipalpus (106-107), O. danum sp.n. (102-103), O. kaharian (100-101) and O. simoni (104-105). 100, 102, 104, 106 - epigyne; 101, 103, 105, 107 - internal structures of epigyne.

Рис. 100-107. Эпигина Onomastus complexinaльna (106-107), O. danum sp.n. (102-103), O. kaharian (100-101) и O. simoni (104-105). 100, 102, 104, 106 - эпигина; 101, 103, 105, 107 - internal structures of эпигина.

second row minute, located on the black protuberance behind anterior laterals. Eyefield distinctly narrowing posteriorly, occupying about half of the length of the carapace. Body slim, about $3 \mathrm{~mm}$ long, pale colored, after preservation white with striking black pigmentation around each eye. Carapace low, with thorax gently sloping, rounded posteriorly. Abdomen elongate oval, narrower than carapace, pointed posteriorly. Legs long and thin (Figs 89-92). Male palpi with broad cymbium and bulbus, differs from average Salticidae by several apophyses, of which the anterior median one is particularly large and broad. Conductor broad and robust, with complicated shape and embolus guiding groove. Embolus long, thread-like. Patella with small apophysis. Epigyne externally resembles a simple depression, but its internal structures are complicated and diversified (Figs 101, 103, 105, 107).

REMARKS. This genus belongs to the subfamily Lyssomaninae. Some workers [Wanless, 1980; Benjamin, 2010] have also called attention to some distant analogies with the family Oxyopidae Thorell, 1870. It is apparently a foliage dweller, documented by existing photographs. The genus contains 12 species distributed in S, SE and E Asia. It was recently revised by Benjamin [2010], who provided superb SEM photographs of the palpal organs. There are three informal, distinct groups within the genus, two of which (kaharian- and patellaris-groups) occur mainly in Sri Lanka, with some species occurring also in India, Thailand, and Borneo: Kalimantan and Hainan in China. The third - complexipalpis group, known from Borneo: Kalimantan and Japan: Okinawa, standout by the structure of the palpal organ and, particularly, by very special internal structure of the epigyne.

Onomastus complexipalpis Wanless, 1980 Figs 89-90, 97-99, 106-107.

O. c. Wanless, 1980: 187, f. $4 \mathrm{a}-\mathrm{f}\left(\sigma^{7}\right)$.

O. c.: Prószyński, 2011 [from the 2003 version], online $\left(\sigma^{\top}+\right)$.

O. c.: Benjamin, 2010: 722-723, f 2A-H, 3A-B ( $\mathrm{O}^{7}+$ ).

MATERIAL. $1 \sigma^{\top} 19$, Kalimantan: Palangkaraya, secondary forest, from leaves, 09.1985, (SD). CDML.

DIAGNOSIS. Males differ from O. kanoi Ono, 1995 (from Japan: Okinawa), by their enormous expansion of the plate-like, rounded conductor, and by having a very long, thread-like embolus. Females differ from O. simoni Żabka, 1985 (Figs 104-105) by having the copulatory duct twisted into a double spiral, hidden inside a compact, sclerotized body (Figs 106-107).

DESCRIPTION. Male. General appearance shown in Figs 89-90, small spider, pale colored. Measurements (approximate, in $\mathrm{mm}$ ): length of carapace 1.53, length of eyefield 0.70 , height of eyefield 1.00 , length of abdomen 1.75.

Palpus unusually large in proportion to carapace, with broad cymbium, rounded conductor and very long thread- 


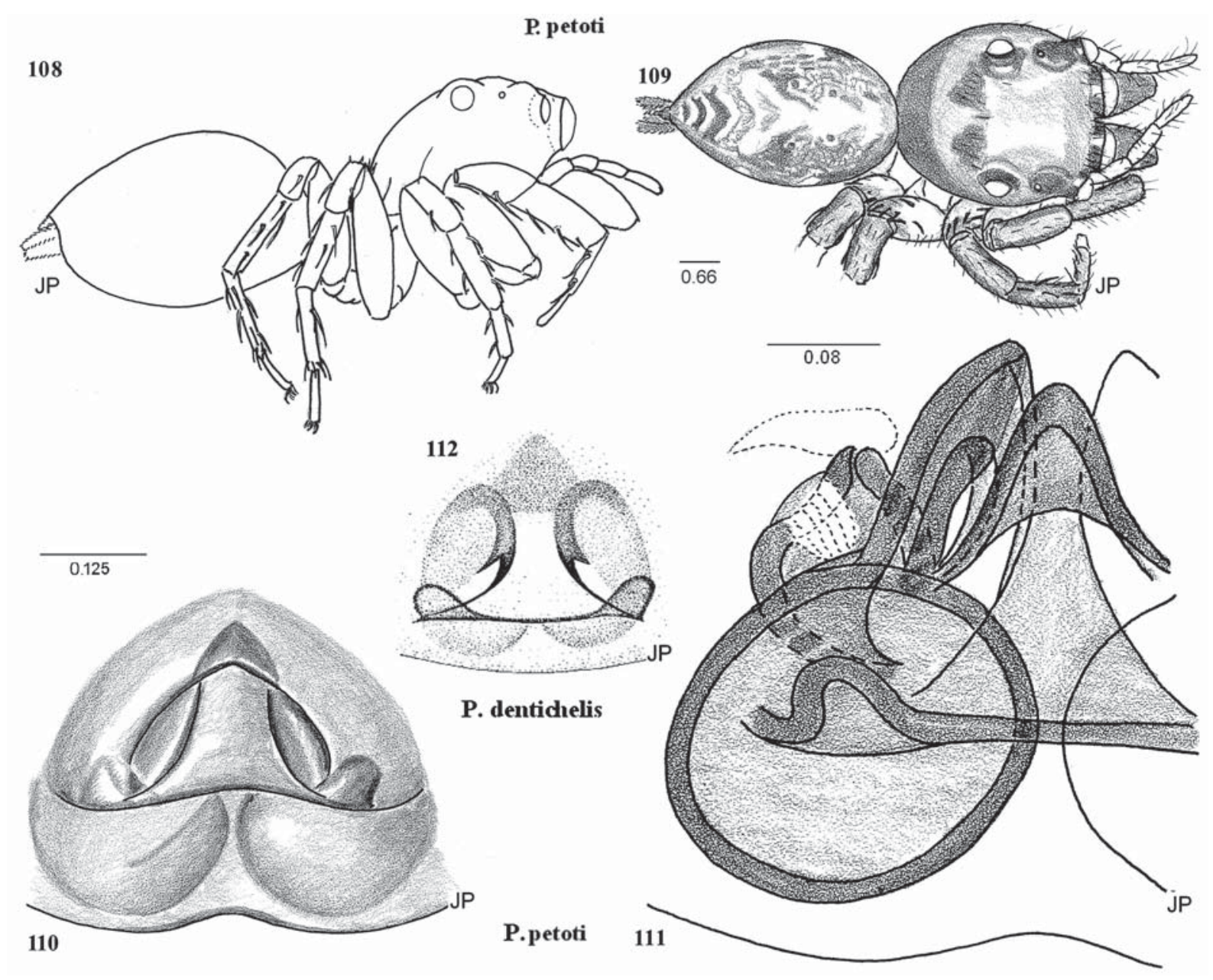

Figs 108-112. General appearance and epigyne of Pancorius petoti sp.n. (108-111) and P. dentichelis (112). 108-109 - general appearance, dorsal and lateral views; 110, 112 - epigyne; 111 - internal structure of epigyne.

Рис. 108-112. Общий видаnd эпигина Pancorius petoti sp.n. (108-111) и P. dentichelis (112). 108-109 — общий вид, dorsal и сбокуs; 110, 112 - эпигина; 111 - внутренние структуры эпигины.

like embolus (Figs 97-99) (see also Benjamin [2010: fig. $2 \mathrm{f}-\mathrm{g}]$ ). Tegulum with several complicated apophyses, including simple posterior tegular apophysis (TA1) and large median apical apophysis (MA), triple branching.

Female. Non-descript tiny, pale spider, details of external appearance not available. There is a good description in Benjamin [2010]. Epigyne with broad oval depression, divided by narrow, incomplete, anterior septum, accompanied with small antero-medial copulatory openings. Main features of epigyne are two large translucent oval bodies, which appear to hide the double-spiraled copulatory duct, visible when cleared and viewed under a microscope. There are two lateral pockets, narrow and indistinct (Fig. 106). Internal structure of epigyne consists of short longitudinal stretch of copulatory duct, which bends transversally and enters a compact sclerotized structure with a double internal spiral of 7 superficial coils, passing into the same number of internal ones, from which the internal duct passes into a compact round body with a few internal coiled chambers (Fig 107). The latter body could be consid- ered a spermatheca (in Benjamin [2010: fig. 3b] interpreted as copulatory ducts), but the nomenclature of such unusual structures is uncertain.

REMARKS. The double spiral of the copulatory duct in the internal structures of the epigyne could be compared with analogous spirals in some species of unrelated genera, like Marpissa Simon, 1868, Yllenus C.L. Koch, 1846, and Telamonia Thorell, 1887. The double spiral form is preceded in these speciose genera by a long chain of species with gradually longer and more complicated ducts [Prószyński, 1968]. By analogy, one could expect a long series of species of Onomastus, either not yet discovered or extinct.

DISTRIBUTION. Documented from Borneo: Kalimantan: Palangkaraya (Indonesia).

\section{Onomastus danum sp.n.}

Figs 91-92, 95-96, 102-103.

MATERIAL. Holotype + , allotype $\sigma^{7}$, Borneo Isl.: E Sabah: Danum Valley Field Centre, primary forest, 6-16.051986 (D-R). CDML. 


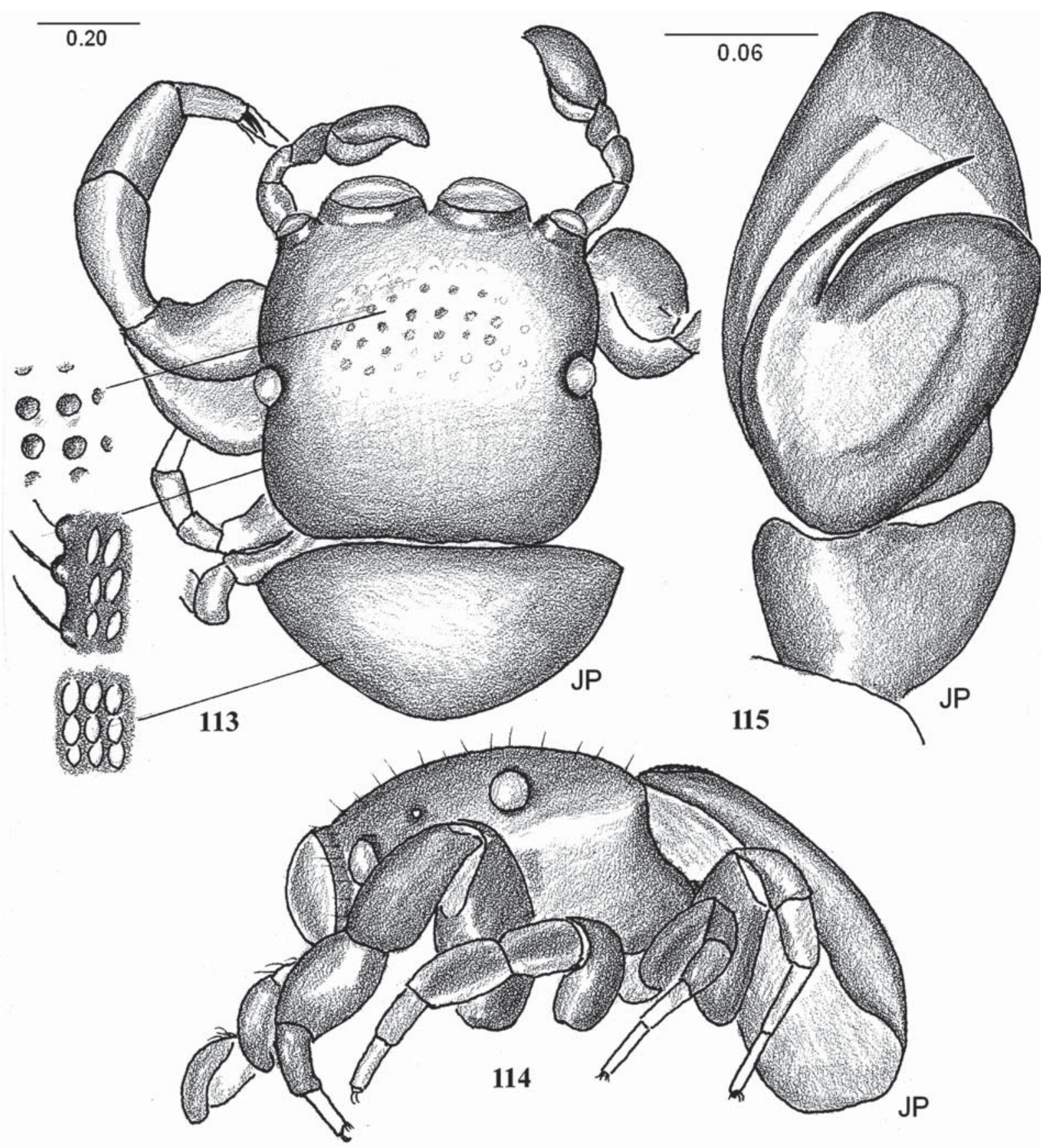

Figs 113-115. General appearance and copulatory organs of Poecilorchestes logunovi sp.n. 113-114 — general appearance, dorsal and lateral views; 115 - palpus, ventral view.

Рис. 113-115. Общий вид и копулятивные органы Poecilorchestes logunovi sp.n. 113-114 - общий вид, сверху и сбоку; 115 пальпа, снизу.

ETYMOLOGY. Specific name - combination of letters, derived from the collection area - Danum Valley.

DIAGNOSIS. Palpal organ strikingly different from O. complexipalpis by the much less expanded conductor, dagger-shaped and positioned across the bulbus (Figs 95-96). The epigyne differs from $O$. simoni (Figs 104-105) by having pocket-like entrances to the copulatory openings in the anterior area, a heavily sclero- tized copulatory duct forming a gently bent semi arch, and spermatheca globular and small (Figs 102-103).

DESCRIPTION. Male. General appearance shown on Figs 91-92. Measurements (approximate): length of carapace 1.35 , eyefield 0.6 , width of eyefield at eyes I 1.0 , width of eyefield at eyes III 0.6 , broadest width of carapace at eyes III 1.0, height of eyefield 0.67 , length of abdomen 1.7, width of abdomen 0.48 , height of abdomen 0.5 . 

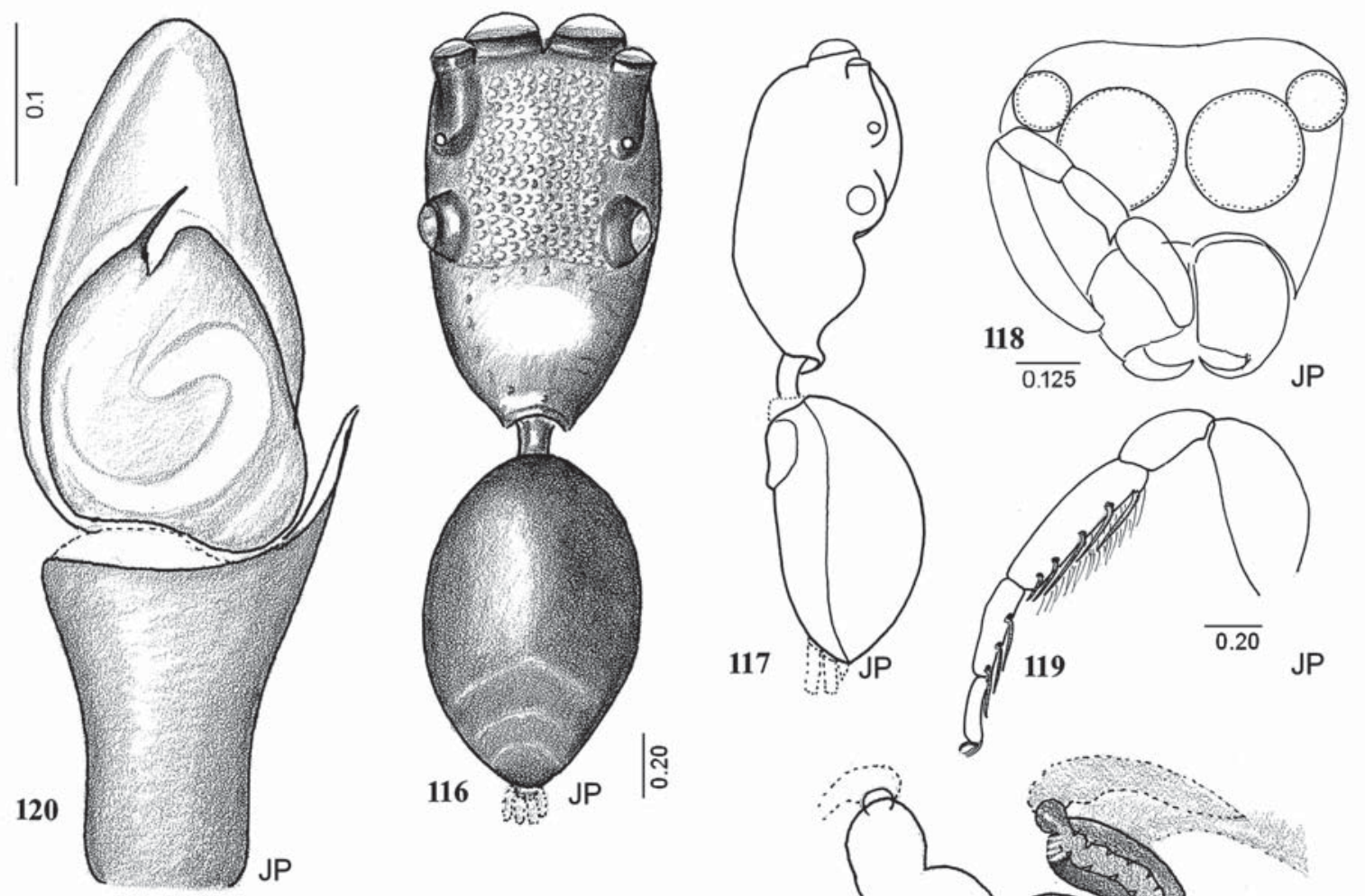

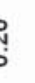

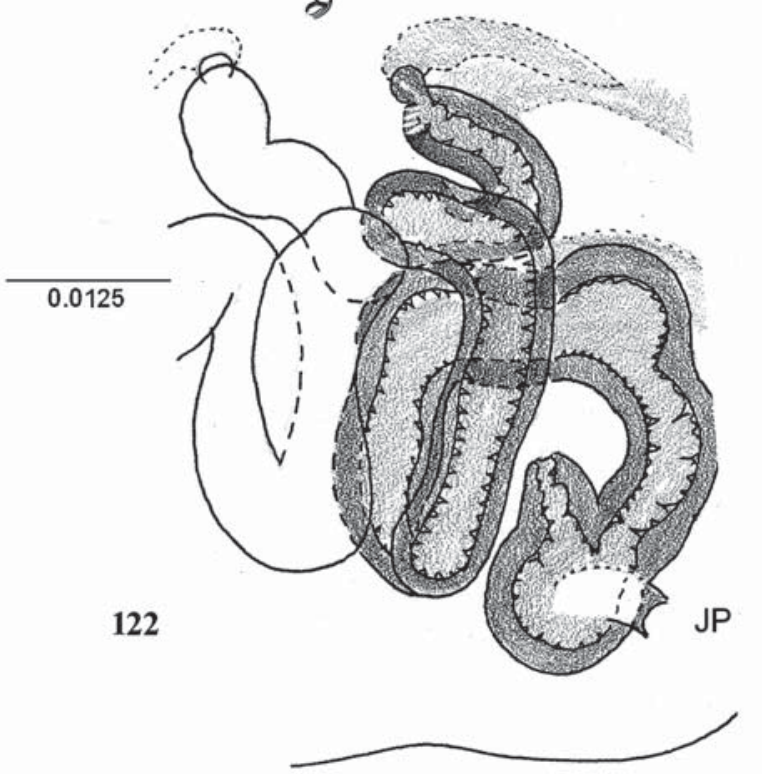

Figs 116-122. General appearance and copulatory organs of Sobasina platnicki sp.n. 116-117 — general appearance, dorsal and lateral views; 118 - face;119 - leg I; 120 - palpus; 121 - epigyne; 122 - internal structure of epigyne.

Рис. 116-122. Общий вид и копулятивные органы Sobasina platnicki sp.n. 116-117 - общий вид, сверху и сбоку; 118 «лицо»; 119 - нога I; 120 - пальпа; 121 - эпигина; 122 - внутренняя структура эпигины.

Palpi thin and relatively short, with large cymbium. Bulbus with relatively robust posterior apophysis (TA1) and very large anterior apophysis (MA), plate-like, with complicated, bent surface, extending close to tip of cymbium (Figs 95-96). Conductor dagger-like with complicated processes, situated across the tip of anterior end of bulbus, with prominent groove of the embolus guide, embolus thread-like, about as long as diameter of bulbus. Patella with small, apically rounded antero-lateral apophysis.
Female. Description of the external appearance not available. Epigyne with central depression, bisected by broad, incomplete anterior septum, and delimited anteriorly by diagonal, sclerotized rims of entrance to pocket-like elongate chambers (Fig. 102). Copulatory ducts and spermathecae unusually thick-walled, forming elongate, heavily sclerotized, compact body. Copulatory ducts gently bent. Spermatheca small, as broad as copulatory ducts (Fig. 103).

DISTRIBUTION. Documented from Borneo: Sabah (Malaysia). 

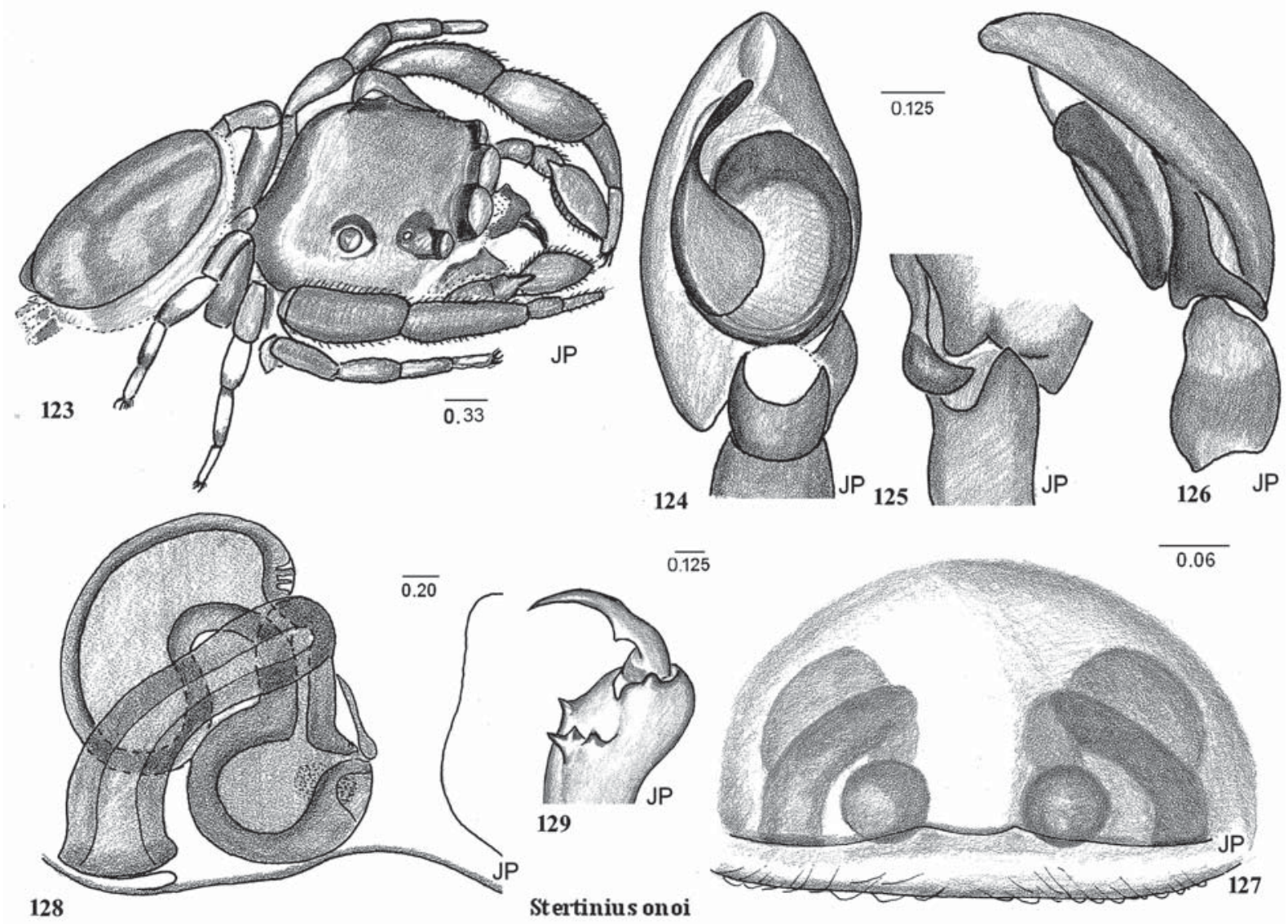

Figs 123-129. General appearance and copulatory organs of Stertinius onoi sp.n. 123 - general appearance; 129 - cheliceral dentition; 124-126 - palpus, ventral and lateral views, tibial apophysis and postrior end of cymbium; 127-128 — epigyne and its internal structure.

Рис. 123-129. Общий вид и копулятивные органы Stertinius onoi sp.n. 123 - общий вид; 129 - вооружение хелицер; 124-126 — пальпа, снизу и сбоку; 127-128 - эпигина и её внутренние структуры.

Onomastus kaharian Benjamin, 2010

Figs 93-94, 100-101.

Onomastus kaharian Benjamin, 2010: 724-728, f. 5A-E, 6A-F/ MATERIAL. $\sigma^{7},+$, , Borneo Isl.: Kalimantan: Kaharian, primary forest, swampy, in foliage, 2-16.09.1984 (SD). CDML.

DIAGNOSIS. Males differ from $O$. danum sp. n. by having a smaller and narrower conductor and a thinner tegular apophysis. Females differ from $O$. danum sp.n. by a constriction in the medial groove in the posterior third of the epigyne and by the lateral copulatory openings.

DESCRIPTION. Male. Pale, slim bodied, elongate but small spider, with long thin legs - see also Benjamin [2010: 728]. Palpus shown in Figs 93-94, with dagger-like conductor, thin tegular apophysis (TA1), broad MA apophysis and pointed patellar apophysis (PA).

Female. Details of external appearance not available — see also Benjamin [2010: 728]. Median groove of epigyne constricted in posterior third, copulatory openings lateral (Fig. 100). Copulatory ducts bent twice, narrower than spermatheca (Fig. 101).
REMARKS. Closely related to other species of the informal kaharian group of species.

DISTRIBUTION. Documented from Borneo: Kalimantan: (Indonesia).

Gen. Pancorius Simon, 1902

Orissania Prószyński, 1992 syn.n., type species Orissania daitarica Prószyński, 1992.

Type species Pancorius dentichelis (Simon, 1899) from Sumatra.

REMARKS. A Plexippinae genus containing 33 species, of which only 9 have diagnostic drawings for both sexes and 14 for one sex. Distributed in warm areas of Asiatic mainland, including China, has 7 species reported from the Malay Archipelago, out of which only 2 are recognizable. One specimen was found in Poland, presumably blown by wind.

\section{Pancorius daitaricus (Prószyński, 1992) comb.n.}

Orissania daitarica Prószyński, 1992 [189-190, f.99, 101105] from India: Orissa. 
NOTE. This species was described from a single female and originally placed in a monotypic genus Orissania Prószyński, 1992. The description of Pancorius petoti sp.n. (see below) demonstrates similarities in the appearance of the epigyne and its internal structures, which are comparable with a number of other Pancorius sp. (Figs 108-111).

\section{Pancorius petoti sp.n.}

Figs 108-111.

MATERIAL. Holotype + , Borneo Isl.: W Sarawak (Malaysia): Semengoh Arboretum, lower track, 23.02.1983 (D-R). CDML.

Comparative species. "20485 Panc.[orius] dentichelis ES. Padang/W” [Sumatra] — coll Simon, MNHN.

ETYMOLOGY. Named for Mr. Didier Petot, the author of the photographs of alive specimens of this species.

DIAGNOSIS. Comparable with $P$. dentichelis (Fig. 112), type species from Sumatra, from which differs in details of shape and proportions of epigyne (Fig. 110-111).

DESCRIPTION. Male unknown. Female. Total length of the body 6.8. Carapace broad and moderately high, with highest point at eyes III (Fig. 108), brown, with lighter brown area around eyefield. Eyefield dark with white contrasting spot in the middle. Abdomen oval, narrower than carapace, pointed posteriorly; brown, with central area consisting of two lighter brown triangles and three small chevrons, appearing lighter due to sparse whitish scales. The remaining abdominal surface is light brown, mottled with diagonal rows of whitish adpressed scales; there are also two pairs of indistinct darker spots (Fig. 109). Face brown with contrasting white rims around eyes, and a few white stout setae on clypeus. Chelicerae brown. Palpi thin, light brown. Coloration of leg I: femur light with brown apical end, patella dark brown, tibia almost black, with scarce white scales and setae, metatarsus lighter brown, tarsus light. Coloration of legs II-IV similar to leg I, but lighter. Epigyne with posterior edge of sclerotized plate distant from epigastric furrow, running across mid-length of anterior, globular spermatheca (Fig. 110). Sclerotized plate with two lateral pockets near the edge and with larger median anterior pocket. There is a triangular central depression, divided by broad medial septum, narrowing anteriorly. Copulatory openings hidden under anterior edges of the central depression, copulatory duct thick walled, extending anteriorly, then making a sharp turn backwards, at about $160^{\circ}$ to join anterior spermatheca. Spermatheca consists of two globular chambers, the anterior one large, the posterior one half the size, with distinct striation of the nutritive pores near the fertilization duct (Fig. 111).

Measurements (approximate, in $\mathrm{mm}$ ): length of carapace 3.4 , length of eyefield 1.65 , height of carapace 2.0 , width of eyefield I 2.64, width of eyefield III 2.64, length of abdomen 3.4, width of abdomen 2.64, height of abdomen 2.0.

DISTRIBUTION. Documented from Borneo: Sarawak (Malaysia).
Gen. Poecilorchestes Simon, 1901

Type species Poecilorchestes decoratus Simon, 1901 from New Guinea; Papua.

REMARKS. A monotypic non-Euophryinae genus of uncertain subfamilial position, belonging to a morphological group of beetle mimicking species, characterized by a thick dorsal tegument, usually light reflecting. It differs from the best-known genus of that group, Coccorchestes Thorell, 1881, which has a palpal organ typical for Euophryinae [Prószyński 1971c: 156-160, f. 1-14].

\section{Poecilorchestes logunovi sp.n.} Figs 113-115.

MATERIAL. Holotype $\sigma^{r}$, Borneo Isl.: W Sabah: Danum Valley Field Centre, lowland primary forest, 10.05.1991 (D-R). CDML.

Comparative species Poecilorchestes decoratus Simon, 1901 No. 5464 from N Guinea: Dorey, Manokwari, coll. Simon, MNHN.

ETYMOLOGY. Named for Dmitri V. Logunov, prominent arachnologist, author of 81 papers on Salticidae.

DIAGNOSIS. Differs from $P$. decoratus [Prószyński, 1971b: 179, f. 45-53] by short, robust legs, and by lack of white spots on carapace and abdomen (Figs 113-115).

DESCRIPTION. Male. Profile of body semicircular (Fig. 114), covered with thick and strong tegument sculptured, with minute pits and covered with sparse, minute whitish, transparent scales (Fig. 113). Dorsally, carapace appears almost square. Eyefield slightly narrowing anteriorly, sloping anteriorly, with highest point above eyes III. Posterior slope of thorax almost vertical, hidden under anterior part of abdominal shield (Fig. 114). Abdomen slightly broader than carapace. Legs short and robust, femur I-tibia I broader than other segments.

Palp with bulbus oval, 0.15 long, spermophor duct following contour of bulbus, embolus arising near midlength of bulbus, narrowing, palpal organ secondarily twisted by approximately $30^{\circ}$ (Fig. 115).

Measurements (approximate, in $\mathrm{mm}$ ): length of carapace 0.70 , length of eyefield 0.40 , height of carapace 0.30 , width of carapace at eyes I 0.60 , width of carapace at eyes III 0.70 , length of abdomen 0.80 , width of abdomen 0.75 .

Female unknown.

DISTRIBUTION. Documented from Borneo: Sabah (Malaysia).

\section{Gen. Sobasina Simon, 1898}

Type Species Sobasina amoenula Simon, 1898 from New Hebrides and Solomon Isl.

REMARKS. This genus belongs to the subfamily Dioleninae and contains 14 species, mostly small and some of which appear ant-like. Their body shape is diverse, there is a constriction of the carapace or abdomen, or both in some species, whereas in others there 

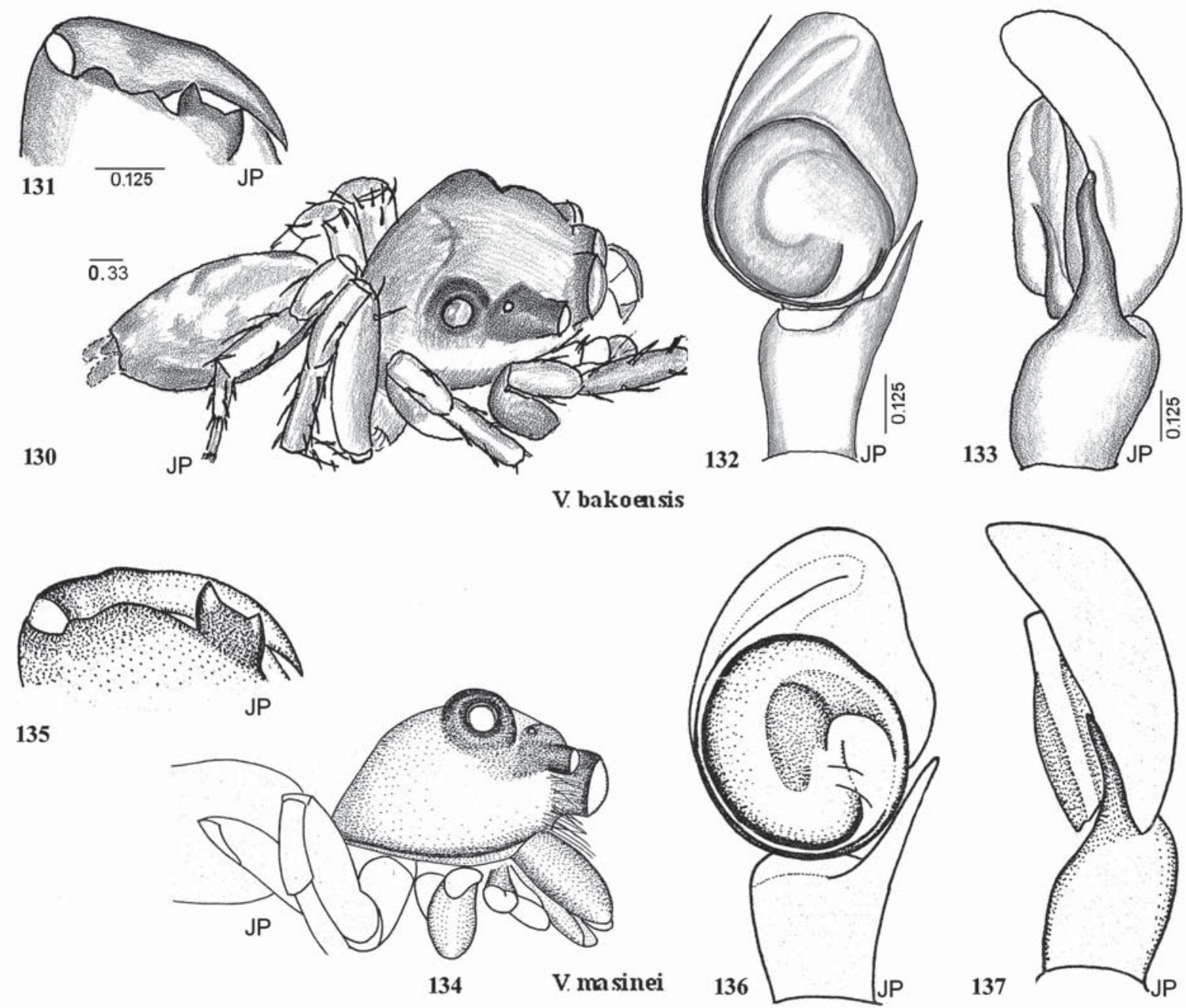

Figs 130-137. General appearance and palpi of Vailimia bakoensis sp.n. (130-133) and V. masinei (134-137). 134, 137 - general appearance; 131, 134 - cheliceral dentition; 132-133, 136-137 — palpi, ventral and lateral views. 134-137 — after Prószyński [1984].

Рис. 130-137. Общий вид и пальпа Vailimia bakoensis sp.n. (130-133) и V. masinei (134-137). 134, 137 - общий вид; 131, 134 - вооружение хелицер; 132-133, 136-137 - пальпа, снизу и сбоку. 134-137 — по Prószyński [1984].

are no constrictions. In some species the constrictions occur in both sexes, whereas in others they may be restricted to one sex only (male or female). Other somatic characters are also diverse. The palpal organs have a simple oval bulbus and a short embolus, originating antero-laterally, the tibial apophysis is thin and short, slightly bent, exceptional in S. sylvatica Edmunds et Prószyński, 2001, where is forked, and followed dorsally by a thin process. The external appearance of the epigyne is difficult to study because it consists of flat, oval plates of small dimensions, which lack any distinct sculpturing. However, the differences in the internal structures of the epigyne are very striking. An unusual feature in these species concerns the development of the spermathecae, which are highly diversified - the posterior part is developed into a very long, narrow duct, forming an initial, reverse Ushaped loop, which continues after turning anteriorly
(Fig. 122). There are delicate teeth along the internal surface of that part of the spermatheca in the majority of species, or a spiral ridge. In $S$. yapensis Berry, Beatty et Prószyński, 1998 the posterior part of the spermatheca has a number of constrictions, resembling string of beads. In S. sylvatica Edmunds et Prószyński, 2001 the posterior part of the spermatheca forms an entangled mass of coils of relatively broad ducts, hiding all other structures, except for the prominent copulatory duct. The anterior part of the spermatheca is relatively small in all species of Sobasina, resembling either a small, globular chamber or an elongate chamber with two swellings. The copulatory ducts can be both short and broad, or not developed; the copulatory opening can be located in different positions, in some species it is distinct, whereas in others it is minute. These can be studied only on cleared and stained (Chlorazol Black E) preparations under a good quality com- 
pound microscope, and descriptions without drawings of such preparations are not reliable for correct taxonomic identification. There is local speciation on the island of Viti Levu, which suggests that comparable, although as yet undiscovered, speciation may occur on other islands as well.

DISTRIBUTION: 13 species are reported from $\mathrm{Pa}-$ cific Islands (including 4 in Fiji), one in continental part of Malaysia, one in N Guinea, none yet in Australia, Indonesia.

\section{Sobasina platnicki sp.n.}

Figs 116-122.

MATERIAL. Holotype $\odot$, allotype $\sigma^{\curvearrowright}$, paratypes $1 \sigma^{x}, 1 \%$, C Kalimantan: Kaharian, swampy primary forest, leaf litter, 2 16.10.1985 (SD). CDML.

ETYMOLOGY. Named for N.I. Platnick, leading authority in Arachnology.

DIAGNOSIS. In comparison with $S$. yapensis Berry, Beatty et Prószyński, 1998 [Berry et al., 1998: 171, f. 67-72] the female differs by the duct-like posterior part of the spermatheca being of uniform width along its whole length (Fig. 122) and not having a series of constrictions. The male differs from $S$. yapensis by having a pear-shaped bulbus, with a more pronounced retrolateral lobe (Fig. 120).

DESCRIPTION. Male. Carapace shallowly constricted dorso-ventrally, behind the eyefield (Fig. 117). Face with large anterior median eyes, diameter of anterior lateral eyes half the size, clypeus low, chelicerae small (Fig. 118). Eyefield almost square, longer than thoracic region, with distinct rugosity. Thoracic region narrowing posteriorly. Petiolus visible from above, 0.12 long. Abdomen oval, shorter than carapace, with hardened, light reflecting surface (Figs 116-117). Legs short, tibia I with five pairs of long spines, metatarsus I with three pairs (Fig. 119). Cymbium longer than tibia, bulbus with well developed postero-lateral lobe, embolus short, parallel to triangular apex of bulbus. Tibial apophysis thin, slightly bent apically, about half the length of bulbus (Fig. 120).

Measurements (approximate): length of carapace 1.15 , length of eyefield 0.68 , width of eyefield I 0.70 , width of eyefield III 0.70 , length of abdomen 1.10 , width of abdomen 0.68 .

Female. Details of general appearance not available. Epigyne transversally oval, delimited anteriorly by bent ridge, with translucent loops of spermathecae, of different length in left and right spermatheca, and two curious, circular depressions (Fig. 121). Copulatory openings very small, invisible externally, located postero-laterally, copulatory ducts membranous, very short and narrow, overlying dark, sclerotized spermathecae. Anterior part of spermatheca small, with diameter and thickness of walls comparable with posterior part, with prominent cone-shaped armature of scent opening. Proximal part of spermatheca forming large and broad, reverse U-shaped loop, extending over the whole length of the epigyne, then making a $180^{\circ}$ turn at the level of the scent opening, before running almost straight anteriorly, before bending medially behind anterior edge of epigyne, and finally forming a half loop. Both parts of spermatheca have walls of the same thickness, their internal surface covered with minute teeth (Fig. 122).

REMARKS. This is the first species of Sobasina reported from Indonesia, including Borneo. This gap in distribution can be explained only by these small spiders having been overlooked by collectors. While the genital organs are most similar to $S$. yapensis from the nearby Caroline Islands, the morphological distance is much greater compared to a species described from Peninsula Malaya - Sobasina sylvatica Edmunds et Prószyński, 2001 [140-142, f. 9-14].

DISTRIBUTION. Documented from Borneo: Kalimantan: (Indonesia).

\section{Gen. Stertinius Simon, 1890}

Type species Stertinius dentichelis Simon, 1890 from Mariana Islands: Guam.

REMARKS. This poorly known SE Asian genus, belongs to the subfamily Simaethineae and contains 12 species, our knowledge of which is limited to drawings of the palpus of one species, epigyne illustrations for two species, the general appearance of the female for one species, and four species are illustrated by drawings of a cheliceral tooth, useless for diagnostic purposes. The species described below is identified following comparison with the internal structure of the epigyne of S. kumadai Logunov, Ikeda et Ono, 1997, from Japan. There are also some similarities to Ligurra opelli Berry, Beatty et Prószyński, 1997 [Berry et al., 1997: 128-129, f 75-80] from the Caroline Islands, in terms of body shape, the base of the embolus and the small tongue-shaped process at the ventro-posterior angle of the cymbium, in addition to the internal structure of the epigyne - these similarities warrant further comparison and, perhaps revision. The absence of a median pocket in $S$. onoi $\mathrm{sp}$. n. deserves some consideration because it is present in the majority of Simaethineae, including the two above-mentioned species.

\section{Stertinius onoi sp.n.}

$$
\text { Figs 123-129. }
$$

MATERIAL. Holotype + , allotype $\sigma^{\top}$, Kalimantan, $40 \mathrm{~km}$ NW of Palang-Karaya, secondary forest, from leaves, 1.10.1985 (SD). CDML.

DIAGNOSIS. The internal structures of the epigyne resemble those in S. kumadai Logunov et al., 1997. The new species differs having swollen chambers of the spermatheca (Fig. 128). The cymbium of the male palpus has a large prolateral posterior flap (Fig. 124), not reported from other species of the genus.

DIAGNOSIS. Internal structures of epigyne resemble these in S. kumadai Logunov, Ikeda et Ono, 1997. The new species differs by swollen chambers of spermatheca (Fig. 128). Male palpus with cymbium having 


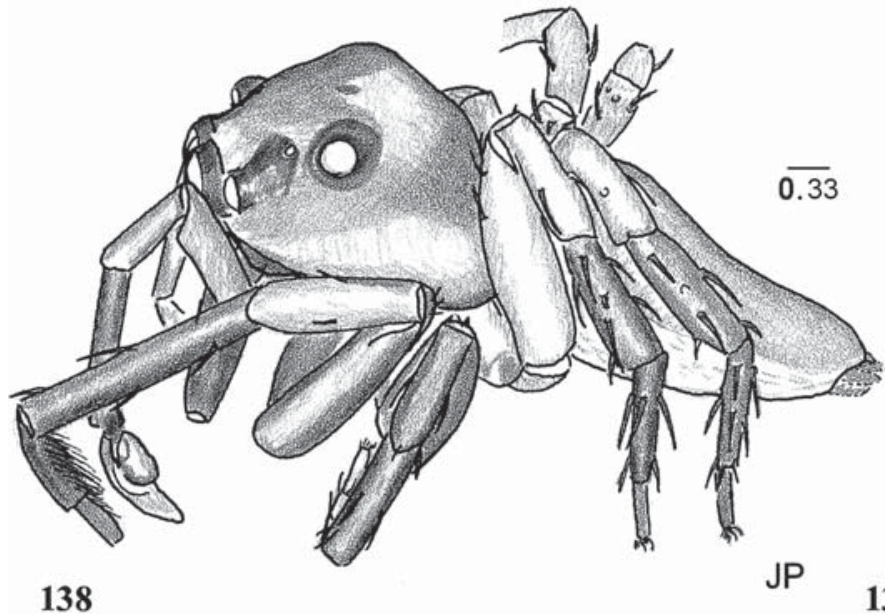

139

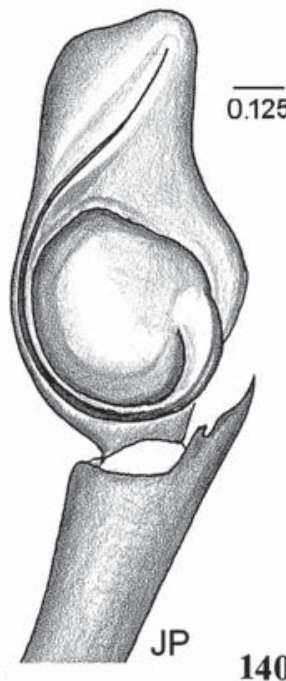

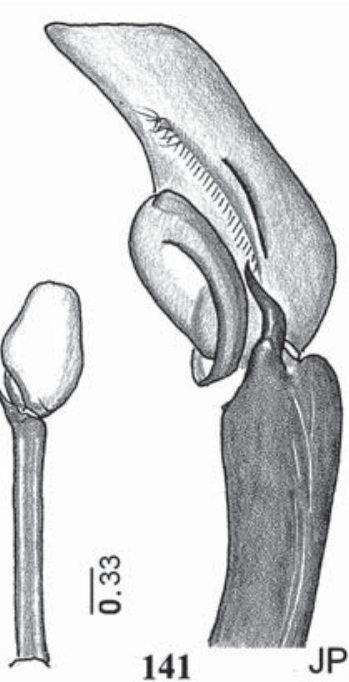

Figs 138-141. General appearance and copulatory organs of Vailimia jianyuae sp.n. 138 - general appearance; 139-141 - palpi, ventral, dorsal and lateral views.

Рис. 138-141. Общий вид и копулятивные органы Vailimia jianyuae sp.n. 138 - общий вид; 139-141 — пальпа, снизу, сверху и сбоку.

large prolateral posterior flap (Fig. 124), not reported from other species of the genus.

DESCRIPTION. Male. Small spider, with carapace 1.65 long, broad, moderately high, dark, lighter beyond eyefield and on upper sides. Eyefield broadening posteriorly, eyes II very close to eyes anterior lateral, located on a pigmented protuberance. Clypeus with a band of white setae. Abdomen 2.14 long, oval, flattened dorsally and covered by scutum. Sides softer and lighter. Legs short, first pair dark and more robust, legs II dark, legs III and IV light with dark femora and distal ends of tibiae and metatarsi (Fig. 123). Chelicerae robust, with wavy fang, inner posterior tooth with three cones arising from a common base (Fig. 129). Palpal tibia short and narrow, armored with short but broad, triangular apophysis, articulating with shallow notch on cymbium. Cymbium retrolaterally with short, tongue-like process along the notch. Prolateral wall of cymbium extended beyond end of bulbus forming a plate reaching end of tibia (Figs 124). Bulbus oval, with spermophore duct extending along margins. Embolus flattened, narrow, arising from plate-like base superimposed on surface of bulbus.

Female. Details of general appearance not available. Epigyne oval, without external pocket (Fig. 127). Spermatheca located in posterior half of epigyne, consisting of two oval chambers, separated by narrower junction. Scent opening armature reduced to three small pores piercing wall of anterior spermatheca. Copulatory duct, broad and thick walled, joining narrow junction between both chambers of spermatheca (Fig. 128). Copulatory openings slit-like at posterior edge of epigyne.

REMARKS. Placement in this genus is based on the similarity of the epigyne to S. kumadai, however, the definition of the genus is uncertain because the genital organs of the type species are unknown.
DISTRIBUTION. Documented from Borneo: Kalimantan: (Indonesia).

\section{Genus Vailimia Kammerer, 2006}

Type species Vailima masinei Peckham et Peckham, 1907 from Borneo.

REMARKS. This genus is very poorly known, originally described from a single species (from a single specimen) described from Borneo Isl.: Sarawak (Malaysia). Another species (again described from a single specimen) was described from Hainan Island. This scanty material does not permit conclusions on diversity, although striking differences in length of the palpal tibiae raises some questions. However, the congeneric status of both species is based on similarities of the palpal organs (Figs 132-133, 136-137, 139, 141) and general appearance (Figs 130, 134, 138). Shared characters of both species are the high carapace, highest at eyes III, with eyefield inclined anteriorly. There is no flat part of the thoracic region (Fig. 134); the posterior slope of the thoracic region is steep, beginning just behind the eyefield. The retromarginal cheliceral tooth has two broad cusps separated by a broad, level ridge (Figs 131-135). Male palpi with cymbium broad and short, with rounded bulbus, half encircled by the embolus (Figs 136-137), resembling the palp in the genus Telamonia Thorell, 1887 (type species T. festiva Thorell, 1887), they are also similar in having a row of stout, but very short setae along the edge of the cymbial groove. The relative length of the legs (according to Peckham \& Peckham [1907]) is I, III, IV, II.

The similarity of the palpus to those of Telamonia may indicate a relationship to the large subfamily Plexippineae, in which the bulbus is often rounded and encircled by the embolus, or to the group of subfamiles 
Plexippoida, as proposed by genetic analysis by Maddison et al. [2008]. The difficulty is that there is broad diversity of palpi within that subfamily; on the other hand similar forms appear in other subfamilies as well, so this problem requires further studies.

Two more species, described below as new, repeat the differences in the length of the palpal tibia as observed in the two previously known species.

DISTRIBUTION. Reported from Borneo: Sarawak (Malaysia), and from Hainan Island, China:.

\section{Vailimia bakoensis sp.n.}

Figs 130-133.

MATERIAL. Holotype O`, Sarawak (Malaysia): Bako National Park, either 28.03.1982, or 1.04.1985 (D-R). CDML.

Comparative material. 1 O $^{\top} V$. masinei Peckham et Peckham, 1907. Borneo Isl. TYPE. Coll. Peckhams: MCZ.

ETYMOLOGY. Name relates to the collecting area - Bako National Park in Sarawak.

DIAGNOSIS. Differs from its sibling species $V$. masinei (Figs 134-137) by having a wavy tibial apophysis and the embolus arising from the bulbus at a 5 o'clock position, whereas in the type species it originates at 3 o'clock (Figs 132, 136).

DESCRIPTION. Male. Carapace as long as abdomen (Fig. 130). Eyefield is broadest and highest at eyes III, from which it slopes anteriorly. Cheliceral dentition bicuspid (Fig. 131). Carapace dark, with white belt along middle of lateral surface, eyefield with light adpressed setae. Abdomen oval, narrower and lower than carapace. Legs moderately long and thick, the first pair being the longest. Measurements (approximate): length of carapace 2.47, length of abdomen 2.47.

Palpus relatively small, with cymbium longer and broader than tibia. Bulbus rounded, rim flattened antero-diagonally, with broad spermophor duct along margin of bulbus (Figs 132-133).

Female unknown.

DISTRIBUTION. Documented from Borneo: Sarawak (Malaysia).

\section{Vailimia jianyuae sp.n.}

Figs 138-141.

MATERIAL. Holotype $\sigma^{\top}$, Sarawak (Malaysia): Bako National Park, 28.03.1982, 1.04.1985 (D-R). CDML.

ETYMOLOGY. Named after Miss Jianyu Guo, a student of Salticidae of Hainan.

DIAGNOSIS. This species resembles the type species in both body shape and structure of the palpal organ, but differs by having longer palpi and legs: palpal tibia almost 1.7 times longer and almost three times narrower than cymbium, like $V$. longitibia Guo, Zhang et Zhu, 2011 [Guo et al., 2011: 1, f. 1-6].

DESCRIPTION. Male. Carapace high and short, as long as abdomen (Fig. 138). Eyefield broadest and highest at eyes III, sloping anteriorly. Carapace dark, with white belt along lower lateral surface and irregular light spot behind eyefield, with light adpressed setae. Abdomen oval, narrower than carapace, lower, but relatively high anteriorly and sloping towards posterior end. Legs moderately long, tibia I and patella I particularly long, tibiae and metatarsi I-IV black. Measurements (approximate, in $\mathrm{mm}$ ): length of carapace 2.70 , length of abdomen 2.70 .

Palpus very long (Fig. 140) owing to unusual length of tibia. Tibial apophysis narrow, wavy, with a small notch at the base. Bulbus roundish, half encircled by embolus which arises at a 3 o'clock position. Rim flattened antero-laterally, with broad spermophor duct along margin of bulbus (Figs 139, 141). Measurements (approximate, in $\mathrm{mm}$ ): length of carapace 2.70, length of abdomen 2.70.

Female unknown.

DISTRIBUTION. Documented from Borneo: Sarawak (Malaysia).

ACKNOWLEDGMENTS. We are grateful to the late Suharto Djojosudharmo who collected spiders in many parts of Indonesia, during the years 1983-2000, kept now in this collection, including those mentioned in this paper. We are particularly grateful to the referees: P. Koomen and W.P. Maddison for very valuable corrections and comments.

Permissions to reproduce a few comparative drawings from his papers were received from Dr. M. Żabka. Of great help were photographs by P. Koomen and by Yu.M. Marusik, the latter has also helped to shape manuscript. Coquille paper for drawings was donated by Dr. W.P. Berry. The translation into English language was corrected by David Penney. Writing of this paper was assisted by special grant No. 303341235 from the Ministry of Higher Education and Sciences of Poland, we are also grateful for the administrative help from the Museum and Institute of Zoology, Polish Academy of Sciences in Warsaw. The authors express their sincere and warm thanks to above mentioned persons and institutions.

\section{References}

Benjamin S.P. 2010. Revision and cladistic analysis of the jumping spider genus Onomastus (Araneae: Salticidae) // Zoological Journal of the Linnean Society, London. Vol.159. P.711745.

Berry J.W., Beatty J.A., Prószyński J. 1996. Salticidae of the Pacific Islands. I. Distribution of twelve Genera, with description of eighteen new species // Journal of Arachnology. Vol.24. No.30. P.214-253.

Berry J.W., Beatty J.A., Prószyński J. 1997. Salticidae of the Pacific Islands. II. Distribution of nine genera, with description of eleven new species // Journal of Arachnology. Vol.25. No.2. P.109-136.

Berry J.W., Beatty J.A., Prószyński J. 1998. Salticidae of the Pacific Islands. III. Distribution of seven genera, with description of nineteen new species and two new genera // Journal of Arachnology. Vol.26. No.2. P.149-189.

Edmunds M., Prószyński J. 2001. New species of Malayasian Agorius and Sobasina (Araneae: Salticidae) // Bullentin of the British Arachnological Society. Vol.12. Pt.3. P.139-143.

Edwards G.B. 2009. Males of Gambaquezonia itimana (Araneae, Salticidae), with notes on females // Journal of Arachnology. Vol.37. No.2. P. 103-105.

Doleschall C.L. 1859. Tweede Bijdrage tot de Kennis der Arachniden van den Indischen Arachipel // Acta Societatis scientiarum Indo-Neerlandicae. Vol.5. P.1-60. 
Guo J.Y., Zhang F., Zhu M.S. 2011. One new recorded genus and one new species of the family Salticidae (Arachnida:Araneae) from China // Acta Arachnologica Sinica. Vol.20. No.1. P. $1-3$

Kammerer C.F. 2006. Notes on some preoccupied names in $\mathrm{Ar}-$ thropoda // Acta Zootaxonomica Sinica. Vol.31. P.269-271.

Keyserling E. 1882. Die Arachniden Australiens, nach der Natur beschriebene und abgebildet. Nürnberg. Bd.1. S.1325-1420.

Keyserling E. 1883. Die Arachniden Australiens, nach der Natu beschriebene und abgebildet. Nürnberg. Bd.1. S.1421-1489.

Koch C.L. 1834. Arachniden // Panzer. Faunae Insectorum Germaniae initia. H.122-127.

Koch C.L. 1846. Die Arachniden. Nürnberg. Bd.13. S.1-234.

Logunov D.V., Ikeda H., Ono H. 1997. Jumping spiders of the Genera Harmochirus, Bianor and Stertinius (Araneae, Salticidae) from Japan // Bulletin of the National Science Museum, Series A (Zoology). Tokyo. Vol.23. No.1. P.1-16.

Logunov D.V. 2000. Redefinition of the Genus Bianor Peckham et Peckham, 1885 and Harmochirus Simon, 1885, with establishment of a new genus Sibianor gen. n. (Aranei, Salticidae) // Arthropoda Selecta.Vol. 9. No.4. P.221-286.

Maddison W.P., Hedin M.C. 2003. Jumping spiders phylogeny // Invertebrate Systematics. Vol.17. P.529-549.

Maddison W.P., Bodner M.R., Needham K.M. 2008. Salticid spider phylogeny revisited, with the discovery of a large Australasian clade (Araneae: Salticidae) // Zootaxa. No.1893. P.49-64.

Merian P. 1911. Die Spinnenfauna von Celebes. Beiträge zur Tiergeographie im Indo-australischen Archipel // Zoologische Jahrbücher. II Abteilung für Systematik. Bd.31. S.165-354.

Ono H., Ikeda H., Kono R. 2009. Salticidae // Ono H. (ed.). The Spiders of Japan with keys to the families and genera and illustrations of the species. Kanagawa: Tokai Univ. Press. P.558-588.

Peckham G.W., Peckham E.G. 1907. The Attidae of Borneo Isl. // Transactions of the Wisconsin Academy of Sciences, Arts and Letters. Vol.15. P.603-653.

Platnick N.I. 2011. The World Spider Catalog, ver. 1-11.5. Online. http://research.amnh.org/iz/spiders/catalog/SALTICIDAE.htm

Prószyński J. 1968. Systematic revision of the genus Yllenus Simon, 1868 (Araneida, Salticidae) // Annales zoologici PAN. T.28. P.409-494.

Prószyński J. 1971a. Catalogue of Salticidae (Aranei) specimens kept in major collections of the world // Annales zoologici PAN. T.28. No.17. P.367-519.

Prószyński 1971b. Redescriptions of the type-species of genera of Salticidae (Aranei). VIII-X. Revision of the subfamily Coccorchestinae // Annales zoologici PAN. T.28. No.9. P.153-182.

Prószyński J. 1984. Atlas rysunków diagnostycznych mniej znanych Salticidae. Zeszyty Naukowe WSRP. Siedlce. 177 p.

Prószyński J. 1987. Atlas rysunków diagnostycznych mniej znanych Salticidae 2. Zeszyty Naukowe WSRP. Siedlce. 172 p.

Prószyński J. 1989. Salticidae (Araneae) of Saudi Arabia // Fauna of Saudi Arabia. Vol.10. P.31-64

Prószyński J. 1992. Salticidae (Araneae) of India in the collection of the Hungarian National Natural History Museum in Budapest // Annales zoologici PAN. T.44. No.9. P.165-227.

Prószyński J. 1996. Salticidae (Araneae) distribution over Indonesian and Pacific Islands // Revue Suisse de Zoologie. Vol. hors serie. P.531-536.

Prószyński J. 2012. Monograph of Salticidae (Araneae) of the World // Internet, version 2012. http://www.miiz.waw.pl/salticid/main.htm, [version summing up previous versions since 1995]

Prószyński J., Deeleman-Reinhold C.L. 2010. Description of some Salticidae (Araneae) from the Malay Archipelago. I. Salticidae of the Lesser Sunda Islands, with coments on related species // Arthropoda Selecta. Vol.19. No.3. P.153-188.

Prószyński J., Deeleman-Reinhold C. L. 2012. Description of some Salticidae (Araneae) from the Malay Archipelago. II. Salticidae of Java and Sumatra, with comments on related species // Arthropoda Selecta. Vol.21. No.1. P.29-60.

Roewer C.F. 1938. Résultats scientifiques du voyage aux indes orientales néerlandaises de la SS. AA. RR. le Prince et la Princesse Leopold de Belgique. Araneae // Mémoires du Musée royal d'histoire naturelle de Belgique. (Hors Serie). Vol.3. No.19. P.1-94.

Simon E. 1868. Monographie des especes europeennes de la famille des Attides (Attidae Sundewall - Saltigradae Latreille) // Annales de la Société entomologique de France. T.4. N.8. P. 11$72,529-726$.

Simon E. 1876. Les Arachnides de France. Paris. T.3. P.1-364.

Simon E. 1877. Etudes arachnologiques. 5e Memoire. IX. Arachnides recueillis aux illes Philippines par MM. G.A. Baer et Laglaise // Annales de la Société entomologique de France. Ser.5. T.7. P.53-96.

Simon E. 1890. Etudes arachnologiques. 22e Mémoire. XXXVI. Arachnides recueillis aux îles Mariannes par M.A. Marche // Annales de la Société entomologique de France. T.61. P.131136.

Simon E. 1899. Contribution a la faune de Sumatra. Arachnides recueillis par M. J. L. Weyers, a Sumatra. (Deuxieme memoire) // Annales de la Société entomologique de Belgique. T.43. P.78-125.

Simon E. 1900. Etudes arachnologiques. 30e Memoire. XLVII. Description d'especes nouvelles de la famille des Attidae // Annales de la Société entomologique de France. T.69. P.2761.

Simon E. 1902. Description d'Arachnides nouveaux de la famille des Salticidae (Attidae) (suite) // Annales de la Société entomologique de Belgique. T.46. P.24-56, 363-406.

Simon E. 1901-1903. Histoire Naturelle des Araignées. Paris. T.2. P.381-1080.

Thorell T. 1881. Studi sui Ragni Malesi e Papuani. III. Ragni dell'Austro Malesia e del Capo York, conservati nel Museo civico di storia naturale di Genova // Annali del Museo civico di Storia naturale. T.17. P.1-720.

Thorell T. 1887. Viaggio di L. Fea in Birmania e regioni vicine. II Primo saggio sui ragni birmani // Annali del Museo civico di Storia naturale di Genova. T.25. P.5-417.

Thorell T. 1890. Diagnoses aranearum aliquot novarum in IndoMalesia inventarum // Annali del Museo civico di Storia naturale. T.30. P.132-172.

Walckenaer C.A. 1802. Faune parisienne. Insectes ou Historie parisienne // Insectes des environs de Paris. T.2. P.187-250.

Wallace A.R. 1855. On the law which has regulated the introduction of new species // Annals and Magazine of Natural History. Ser.2. Vol.16. P.184-196.

Wanless F.R. 1980. A revision of the spider genus Onomastus (Araneae, Salticidae) // Bulletin of the British Museum (Natural History) (Zoology series). Vol.39. No.3. P.179-188.

Zhang J., Maddison W.P. 2012. New euophryine jumping spiders from Papua New Guinea (Araneae: Salticidae: Euophryinae) // Zootaxa. No.3491. P.1-74.

Żabka M. 1985. Systematic and zoogeographic study on the family Salticidae (Araneae) from Viet-Nam // Annales zoologici PAN. T.39. No.11. P.197-485.

Żabka M. 1988. Salticidae (Araneae) of Oriental, Australian and Pacific Regions III // Annales zoologici PAN. T.41. No.14. P.421-479.

Responsible editor Yu.M. Marusik 